CHANG-TAI HSIEH

University of Chicago

ZHENG (MICHAEL) SONG

Chinese University of Hong Kong

\title{
Grasp the Large, Let Go of the Small: The Transformation of the State Sector in China
}

\begin{abstract}
In the late 1990s, China's industrial sector was dominated by state-owned firms. We document how this changed after 1998. More than 80 percent of the state-owned firms in 1998 were shut down or privatized by 2007. Among firms we classify as state-controlled in 2007, many were restructured and registered as private firms with a controlling share held by a stateowned conglomerate or were new firms established after 1998. In 2007, almost half of the state-controlled firms were registered as private firms, and about 40 percent were new firms established after 1998. The privatization and convergence in labor productivity decelerated after 2007, but the establishment of new state-owned firms continued at roughly the same rate. When we interpret these facts through the lens of an equilibrium model of heterogeneous firms, we find that the transformation of firms that remained under state control and the creation of new state-controlled firms together account for 21 percent of China's growth from 1998 to 2007 and 18 percent of its growth from 2007 to 2012. However, the exit and privatization of state-owned firms had a negligible effect on aggregate growth.
\end{abstract}

central feature of the industrial revolution in China over the last two decades is the decline of the state-owned sector. Figure 1 illustrates that the share of state-owned firms in industrial output declined from 50 percent in 1998 to 30 percent by 2005, and has continued to fall since then, albeit at a slower rate. This fact naturally suggests that China's growth was driven by the growth of the private sector and the reallocation of resources away from state-owned firms. According to a popular view, the growth of the private sector was only possible when, starting in the late 
Figure 1. Revenue Share of State-Owned Firms, 1998-2013

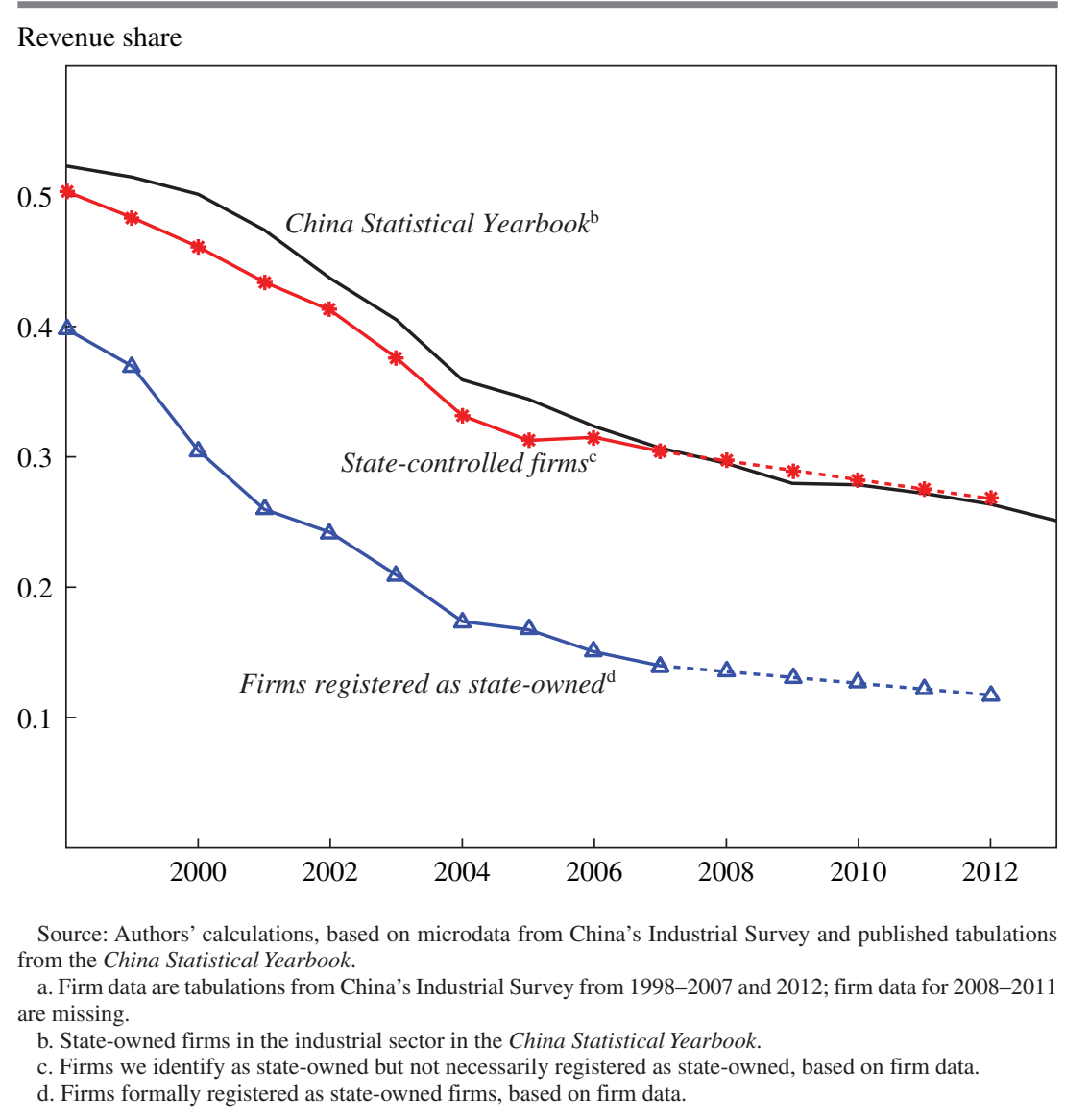

1990s, state-owned firms were shut down or privatized. The shutdown of loss-making state-owned firms released resources that were more profitably employed by private firms. Privatizing state-owned firms may have raised their productivity by more closely aligning control and cash-flow rights. The industrial revolution in China is thus nothing more than the triumph of "Markets over Mao," to quote the title of a recent book by Nicholas Lardy (2014).

Another view is that China's growth was driven by "state capitalism." Advocates of the role of state capitalism point out that although many state-owned firms were closed or privatized, the remaining state-owned firms are among the largest firms in China today. For example, 67 of the 
69 Chinese companies in Fortune's 2014 list of the 500 largest companies in the world are state-owned. One can also point to the experience of specific state-owned companies. Consider, for example, the experience of the Baoshan Steel Company. Baoshan, a large steel manufacturer in Shanghai, became a publicly traded company in $2000 .{ }^{1}$ The controlling share (75 percent) is held by a holding company (the BaoSteel Group) wholly owned by the Chinese central government. ${ }^{2}$ Baoshan has done very well since the late 1990s. Total sales increased from USD 3.7 billion in 2000 to USD 23.1 billion by 2007. Profits increased by even more, from USD 527 million in 2000 to USD 2.2 billion by 2007. Baoshan is currently the largest steel producer in China and one of the largest steel producers in the world. ${ }^{3}$ The experience of Baoshan is an example of how state-owned firms have changed. Such firms, which are among the largest companies in China today, have typically been partially privatized but always with a controlling share held by a large state-owned conglomerate. The term used in China for this ownership change is that large state-owned firms were "corporatized," not privatized. Furthermore, there is a widespread perception that such firms have been enormously successful, perhaps even too successful. For example, a new popular phrase in China is guo jin min tui, which translates roughly as "the state advances, the private sector retreats." Implicit in this slogan is the belief that state-owned firms have been successful, but their success has had negative aggregate effects.

What is missing in this debate is evidence, and this is what we provide in this paper. We use detailed firm-level data from China's Industrial Survey to measure the quantitative importance of the transformation of the state sector on aggregate productivity growth. First, we document the triumph of "Markets over Mao" in the Chinese industrial sector from 1998 to 2007: more than 83 percent of all state-owned firms in the industrial sector in 1998 were shut down or privatized by 2007, with higher rates among smaller state-owned firms. Second, we document the "corporatization" of the surviving state-owned firms: among firms we identify as

1. Technically, Baoshan was closed in 2000, and a new company called Baoshan Company Limited was established with the assets of the old state company and publicly listed on the Shanghai Stock Exchange.

2. Baoshan is legally controlled by the central government's State-Owned Assets Supervision and Administration Commission (SASAC), and Baoshan's senior executives are appointed by the Organization Department of the Chinese Communist Party.

3. These numbers are from Baoshan's annual reports. As we discuss later in the paper, Baoshan is only one of the firms in the BaoSteel Group. 
state-controlled in 2007, almost half are officially registered as private firms. Third, we find that the labor productivity of surviving state-controlled firms and privatized firms converged to that of private firms by 2007, but that capital productivity among state-owned and privatized firms remained about 40 percent lower (compared to private firms). Fourth, we find that many new state-owned firms were established between 1998 and 2007: such firms accounted for approximately 36 percent of all state-owned firms in 2007. Finally, parts of this process decelerated after 2007: after that point there was less privatization of state-owned firms, and the growth in labor productivity of state-owned firms relative to that of private firms slowed down from 2007 to 2012 (compared to the 1998-2007 period), but the creation of new state-owned firms continued after 2007 at roughly the same rate, as in the earlier period.

We then interpret these facts through the lens of an equilibrium model of heterogeneous firms. We find that the exit and privatization of stateowned firms had negligible effects on aggregate output growth, accounting for about 3 percent of the aggregate growth in China's industrial sector from 1998 to 2007 and zero percent of growth from 2007 to 2012. Thus, a simple version of the "Markets over Mao" story for China's growth does not appear to be correct. The bulk of China's growth is driven (in a proximate sense) by two other forces. First, the "corporatization" of the surviving state-controlled firms and the establishment of new state-owned firms collectively accounts for 21 percent of the growth from 1998 to 2007 and 18 percent of the growth from 2007 to 2012 . Second, the residual, which is due to the growth of private firms, accounts for 70 to 80 percent of aggregate growth after 1998. In sum, we find that the quasi-privatization "corporatization" of firms that remained under state control and the creation of new state-controlled firms played an important role in China's growth, but the biggest force behind China's growth is neither state capitalism nor the simple version of the "Markets over Mao" story.

The rest of the paper is organized as follows. Section I presents the facts regarding the characteristics of exiting firms, survivors, and entrants in the state sector relative to that of their private counterparts. In section II, we lay out a model to guide our empirical analysis. We then use the model in section III to back out firm-level productivity and distortions. We also explore the institutional forces behind the dramatic changes in the state sector in section IV. Section V quantifies the effect on aggregate GDP of the reallocation toward private firms through the exit and privatization of state-owned firms and the productivity improvements among surviving state-owned firms. Section VI concludes. 


\section{Grasp the Large, Let Go of the Small}

This section describes the institutional background behind the state sector reforms that began in the late 1990s. We then present a comprehensive set of empirical facts found in China's industrial firm data. We pay special attention to the identification of state ownership, which is often disguised by the firms' legal registration.

The main data we use are the microdata from the Annual Survey of Industries conducted by China's National Bureau of Statistics from 1998 to 2007 and for $2012 .{ }^{4}$ This survey is a census of all state-owned firms and non-state-owned firms (henceforth referred to as private firms) in the industrial sector that have more than 5 million RMB in revenues. ${ }^{5}$ The unit of observation in the data is a registered firm. For the firms owned by the state-owned industrial groups, each firm is a separate observation in our data.

\section{I.A. Institutional Background}

The policy changes we describe below were formally announced in 1999 in the Fourth Plenum of the Communist Party's Central Committee. ${ }^{6}$ The slogan adopted by the Communist Party to describe the proposed reforms was "Grasp the Large, Let Go of the Small." "Let Go of the Small" refers to the fact that small state-owned firms were to be closed or sold.

As for the large state-owned firms, the plan was that large firms were to be "grasped" by the state. By grasp, the central committee meant that large state-owned firms were to be merged into large industrial conglomerates, and the control over these conglomerates was to be consolidated by the central government or by local governments. In the steel sector, for example, five large industrial groups were created in the late 1990s and early 2000s, and ownership of the state-owned steel manufacturers was transferred to these groups. Three of these groups are owned by the Chinese central government (BaoSteel Group, WuSteel Group, and AnSteel Group) and two by provincial governments (Hebei Iron

4. We do not have access to the microdata from 2008 to 2011.

5. The threshold was raised to 20 million RMB in 2011.

6. See Central Committee of the Communist Party of China (1999) for the formal announcement. As is typical with all the major reforms implemented in China, the official decision in 1999 was preceded by several years of small-scale experimentation. See Aivazian, Ge, and Qui (2005) for an assessment of the initial experiments with reforms in corporate governance. 
and Steel Group, and Shandong Steel Group). The BaoSteel Group, for example, controls six large steel manufacturers-three wholly owned by the group and three (including Baoshan) publicly traded with the group as the controlling shareholder.

The automobile industry provides another example. In this sector, stateowned automobile companies were consolidated into six state-owned conglomerates, the largest of which is the Shanghai Automotive Industry Corporation (SAIC) Group owned by the Shanghai local government. The SAIC Group owns a controlling share of the equity (73 percent) of the original state-owned firm (SAIC Motor Co., Ltd.), which is now a publicly traded company. In turn, SAIC Motor Co., Ltd., holds 50 percent of the equity of two new companies jointly established with General Motors (Shanghai-GM) and Volkswagen (Shanghai-Volkswagen). ${ }^{7}$

A more fundamental goal of "Grasp the Large" was to transform the large state-owned firms into profit-maximizing firms under the control of the Chinese state. Two aspects of the reorganization of large state-owned firms were meant to accomplish this goal. First, state-owned firms were often incorporated as limited liability corporations, and the managers were to be held accountable for the firm's bottom line. The terminology used in China was that state-owned firms were to be "corporatized." The parent company, as the controlling shareholder, was to monitor the firm and be responsible for appointing and deciding the compensation of the firm's senior managers. In turn, the senior executives of the parent company (the industrial group) were to be directly appointed by the local government (in the case of groups owned by local governments, such as the SAIC Group) or by the Central Organization Department of the Communist Party (in the case of groups owned by the central government, such as the BaoSteel Group).

In addition, although the plans laid out in the late 1990s did not mention the establishment of new state-owned firms, we will show that this was also an important part of what happened. Because the new state-owned firms are predominantly large firms, we will also label the creation of new stateowned firms as part of what was meant by "Grasp the Large."

The question is how the Chinese state chose to exercise its right of control over the industrial groups and, in particular, what criteria it used to reward and punish the groups' senior executives. In 2003, the State-Owned Assets Supervision and Administration Commission (SASAC) was set up

7. The SAIC Group also owns other companies, but the biggest company under its control is SAIC Motor Co., Ltd. 
as the legal owner of the state-owned groups. ${ }^{8}$ This body was set up simultaneously at the central- and local-government levels. However, the ultimate hiring and firing authority was kept in the hands of the Communist Party's Organization Department. We have little information on how the Organization Department exercised its authority. What we can do is measure the performance of these firms, which we do in the rest of section I.

\section{I.B. State Ownership}

Identifying state-owned firms is key to our analysis. A common way to identify state ownership in China is through the firm's legal registration. Specifically, firms in China are legally registered as state-owned, collectively owned, privately owned, limited-liability corporations, shareholding firms (including publicly traded), or foreign firms. In this system of classification, state ownership is typically defined as being legally registered as state-owned.

There are two problems with using a firm's legal registration to identify ownership, particularly for state-owned firms. First, many firms that are ultimately state-owned are legally registered as foreign firms. This can happen because firms in which at least a third of the ownership is foreignheld can be registered as foreign firms. For example, the joint ventures of the Shanghai local government with GM and Volkswagen (Shanghai-GM and Shanghai-Volkswagen) are registered as foreign firms. This can also happen when the firm is owned by a holding company registered outside of mainland China. For example, Lenovo and China National Offshore Oil Corporation (CNOOC) (a state-owned oil company) are owned by holding companies registered in Hong Kong and, thus, legally registered as foreign firms in China.

Second, many state-owned firms, particularly since 1998, are registered as limited-liability or publicly traded companies, albeit with the controlling stake held by a state-controlled holding company. The Baoshan Steel Company and SAIC Group's stand-alone car company (SAIC Motor Co., Ltd.) are examples of publicly listed companies and thus are registered as share-holding companies. However, for both companies a controlling stake is held by a holding company owned by the Chinese state (the central

8. With the exception of state-owned tobacco companies and state-owned financial institutions, ownership of all state-owned groups was transferred to the SASAC in 2003. Tobacco companies are controlled by the State Tobacco Monopoly Administration and financial institutions by a holding company (Huijin) controlled by China's Banking Regulatory Commission. 
government in the case of Baoshan and the local Shanghai government in the case of SAIC).

Instead of using the firm's legal registration to identify state ownership, we use another approach. First, our data provide the shares of the firm's registered capital that are owned by the state, by a collective, by "private persons," by foreigners, and by "legal persons." Here, a legal person can be another firm or a holding company. For example, publicly traded stateowned firms such as Baoshan and SAIC typically have a minority share of their registered capital held by private persons (the publicly traded share) and a majority share held by a legal person (the state-owned parent holding company). Our data do not provide additional information on the identity of such legal persons, but the share of the registered capital owned by legal persons in the Chinese industrial sector has increased since 1998, particularly among large firms. ${ }^{9}$ Second, our data provide information on the firm's controlling shareholder. In particular, they classify the controlling shareholder of the firm as either the state, a collective, a foreigner, or a private person.

We use these two variables to define state-owned firms. Specifically, we define a firm as state-owned when the share of registered capital held directly by the state exceeds or equals 50 percent or when the state is reported as the controlling shareholder. The former definition captures traditional stateowned firms when the state owns all or the majority of the firm's registered capital. The latter definition captures publicly traded firms when the state holds a controlling stake through a holding company, but excludes firms when the state may hold a minority share through a holding company.

We supplemented this definition of state ownership by manually checking the websites of all the industrial firms in the top one percentile of the firm-value-added distribution in 2007. We find that virtually all the firms that we identified as state-owned through this laborious procedure are also coded as state-owned using our definition. Interestingly, our forensic analysis indicates that of firms in the top one percentile, more than two-thirds are directly or indirectly controlled by SASAC, but almost half of these firms are legally registered as private firms. Our procedure might understate the state share if some companies do not publicly reveal the state's ownership stake on their websites. On the other hand, we might overstate the state

9. Among the firms that survived from 1998 through 2007, the legal person registered capital share was above 10 percent for 22 percent of them in 1998 and for 30 percent of them by 2007 . Among the large firms with the initial value added in the top decile, the shares were 27 and 43 percent in 1998 and 2007, respectively. 
Figure 2. Share of State-Controlled Firms Registered as Private Firms, 1998-2012

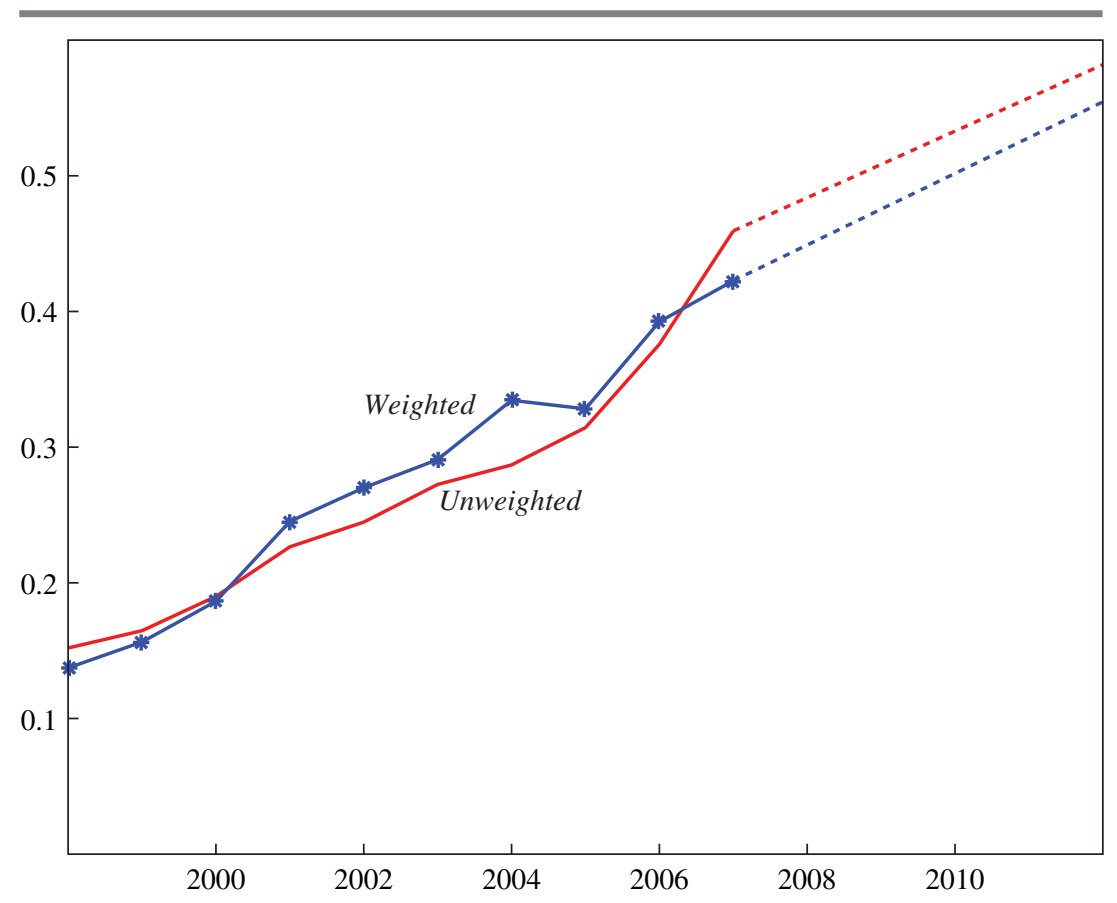

Source: Authors' calculations, based on microdata from China's Industrial Survey.

share if some SASAC firms are ultimately privately owned but use SASAC to mask their ownership stake. For example, the Sydney Morning Herald reported in 2011 that a large shadow bank in Chongqing (Chongqing International Trust) legally owned by the local government of Chongqing was in fact privately owned by an associate of the Party Secretary of Chongqing at the time. ${ }^{10}$

The top panel of figure 1 shows that the revenue share of state-owned firms, by our definition, is similar to that reported by the China Statistical Yearbook. The figure also shows that using the firm's legal registration to define state ownership would understate the size of the state sector. Figure 2 plots the number of state-owned firms that are registered as private firms as a share of the number of firms we define as state-owned. In 1998, approximately 15 percent of state-owned firms were registered as private firms. By

10. John Garnaut, "Bo Can Do! One Man Does His Bit to Be the Great Will of China," Sydney Morning Herald, August 7, 2011. 
Table 1. Firms and Employment by Ownership, 1998-2007

\begin{tabular}{lrr} 
& No. of firms & Employment \\
\hline State-owned in 1998 & & \\
$\quad$ Exit by 2007 & 38.1 & 15,077 \\
State-owned in 2007 & 7.6 & 12,679 \\
$\quad$ Private in 2007 & 5.0 & 3,196 \\
Private in 1998 & & \\
$\quad$ Exit by 2007 & 58.2 & 11,871 \\
$\quad$ Private in 2007 & 28.1 & 8,422 \\
State-owned in 2007 & & \\
$\quad$ Entrant & 4.2 & 2,475 \\
$\quad$ State-owned in 1998 & 7.6 & 9,308 \\
Private in 2007 & & \\
$\quad$ Entrant & 199.4 & 30,767 \\
$\quad$ State-owned in 1998 & 5.0 & 2,512 \\
Private in 1998 & 28.1 & 11,549 \\
\hline
\end{tabular}

Source: Authors' calculations, based on microdata from China's Industrial Survey.

a. Number of firms and employment is in thousands. Entrants in 2007 are the firms established between 1999 and 2007 (inclusive).

2007, almost half of the state-owned firms were registered as some form of privately owned firm. Among state-owned firms registered as private firms in 2007, approximately 60 percent were registered as limited-liability corporations, 16 percent were publicly traded companies, and 18 percent were registered as foreign firms. ${ }^{11}$ This share has continued to rise since 2007; by 2012 almost 60 percent of the state controlled firms were registered as nonstate firms.

Table 1 presents the number and total employment of the firms in our sample in 1998 and 2007. Table 2 presents similar statistics for the sample in 2007 and 2012. ${ }^{12}$

\section{I.C. Size, Labor, and Capital Productivity}

We use firms' registration ID provided in the data to match firms over time. The registration ID may change when a firm is restructured or acquired

11. See the online appendix for details. Online appendixes to all papers in this volume may be found at the Brookings Papers web page, www.brookings.edu/bpea, under "Past Editions."

12. One issue with the data is that because of the size thresholds for inclusion in the sample, some firms that are not in the sample in a given year show up in the data in later years. In table 1, we restrict the 2007 data to firms that were either born after 1998 or that were present in the data in 1998. Similarly, in table 2, we restrict the 2012 sample to firms that were born after 2007 or were present in the data in 2007. 
Table 2. Firms and Employment by Ownership, 2007-12

\begin{tabular}{lrr} 
& No. of firms & Employment \\
\hline State-owned in 2007 & & \\
$\quad$ Exit by 2012 & 9.2 & 4,591 \\
State-owned in 2012 & 8.7 & 11,437 \\
$\quad$ Private in 2012 & 1.4 & 759 \\
Private in 2007 & & \\
$\quad$ Exit by 2012 & 158.9 & 20,822 \\
$\quad$ Private in 2012 & 138.9 & 36,886 \\
State-owned in 2012 & 2.7 & 1,189 \\
$\quad$ Entrant & 8.7 & 10,524 \\
$\quad$ State-owned in 2007 & & \\
Private in 2012 & 70.1 & 15,052 \\
$\quad$ Entrant & 1.4 & 806 \\
$\quad$ State-owned in 2007 & 138.9 & 50,937 \\
$\quad$ Private in 2007 &
\end{tabular}

Source: Authors' calculations, based on microdata from China's Industrial Survey.

by another firm. For the sample of firms that we cannot match over time with the registration ID, we also use the firms' names, addresses, and phone numbers to identify surviving firms that changed their registration ID. ${ }^{13}$ About 95 percent of the panel is identified by the registration ID, while the remainder are matched by firm name, address, and phone number.

The other variables from the 1998-2007 data that we use are value added, employment, and the book value of the firm's capital stock net of depreciation. We define the real capital stock at time $t$ as

$$
K_{t}=(1-\delta) K_{t-1}+\frac{B K_{t}-B K_{t-1}}{P_{t}^{K}},
$$

where $B K$ is the book value of capital and $P^{K}$ is the price of capital. ${ }^{14}$ Labor input is measured by employment, since our data do not include the composition of the firms' labor force. However, as a robustness check we use

13. We follow the procedure used by Brandt, Van Biesebroeck, and Zhang (2012).

14. We use Perkins and Rawski's (2008) estimates of the price of capital. The initial book value of capital stock is initial book value reported by the firm for firms established after 1998. For firms founded before 1998, we assume that the book value in 1998 is given by $B K_{t_{0}}=B K_{t_{1}} /(1+g)^{t_{1}-t_{0}}$, where $B K_{t_{0}}$ is the projected initial book value of the capital stock in year $t_{0} ; B K_{t_{1}}$ is the book value of capital stock when the firm first appears in the data set in year $t_{1}$; and $g$ is the average growth rate of the capital stock in the period we observe in the data after year $t_{1}$. 
Table 3. Annual Exit Rate, 1991-2012

Percent

\begin{tabular}{lccc} 
& $1991-95$ & $1998-2007$ & $2007-12$ \\
\hline State-owned $^{\mathrm{a}}$ & 0.9 & 13.2 & 15.8 \\
Private & 13.2 & 12.0 & 13.8
\end{tabular}

Source: The exit rates from 1998 to 2007 and from 2007 to 2012 are computed from China's Industrial Survey. The exit rate from 1991 to 1995 is computed from the 1996 China Statistical Yearbook and the microdata of the 1995 Industrial Census.

a. State-owned firms that were privatized are not considered exiting firms.

the firm-level records of the 2004 Economic Census (which has information on the educational composition of firms' labor force) to measure differences in labor quality across firms. The 2012 data do not have the value added or the net book value of the capital stock. In the 2007-12 panel, we use revenues instead of value added and the gross book value of the capital stock instead of the real capital stock.

To control for industry effects, all the firm-level variables we present are, unless otherwise stated, scaled by the median values of surviving private firms in the same two-digit industry.

EXITERS Table 3 presents the average annual exit rate for state-owned and privately owned firms for the 1991-95, 1998-2007, and 2007-12 time periods. ${ }^{15}$ The average exit rate for state-owned firms was under one percent a year from 1991 to 1995 and increased to approximately 13 and 16 percent a year in 1998-2007 and 2007-12, respectively. Among private firms, the exit rate was roughly similar across the three time periods, at about 12 to 13 percent a year. Figure 3 presents the average annual exit rate from 1998 to 2007 (top panel) and 2007 to 2012 (bottom panel) of stateowned and private firms for each size bin as defined by the firms' value added in 1998 and 2007, respectively. Exit rates of smaller state-owned firms are higher than those of comparably sized private firms. The annual exit rate from 1998 to 2007 exceeds 30 percent among state-owned firms in the bottom 10th percentile of the size distribution, about 10 percentage points higher than comparably sized private firms over the same time period. Exit rates for small state-owned firms from 2007 to 2012 are also

15. The exit rates from 1998 to 2007 and from 2007 to 2012 are computed from the Industrial Survey. The exit rate from 1991 to 1995 is computed from the 1996 China Statistical Yearbook and the microdata of the 1995 Industrial Census. State-owned firms that were privatized are not considered exiting firms. See the online appendix for additional details. 
Figure 3. Annual Exit Rate, 1998-2007 and 2007-12

1998-2007

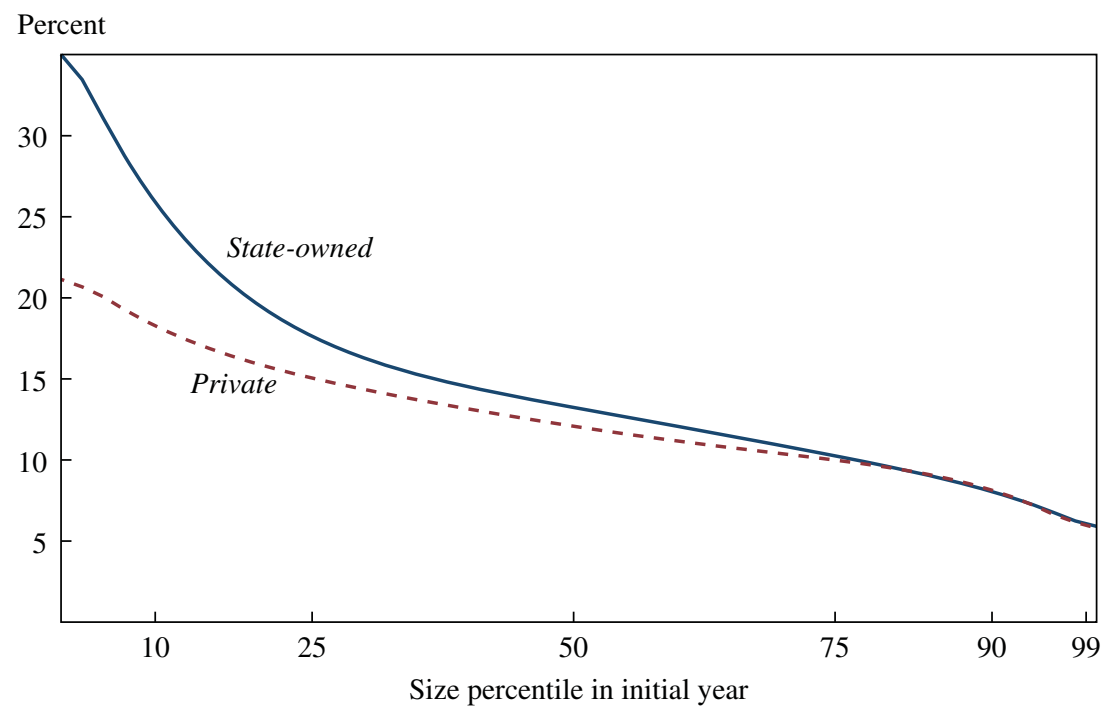

2007-12

Percent

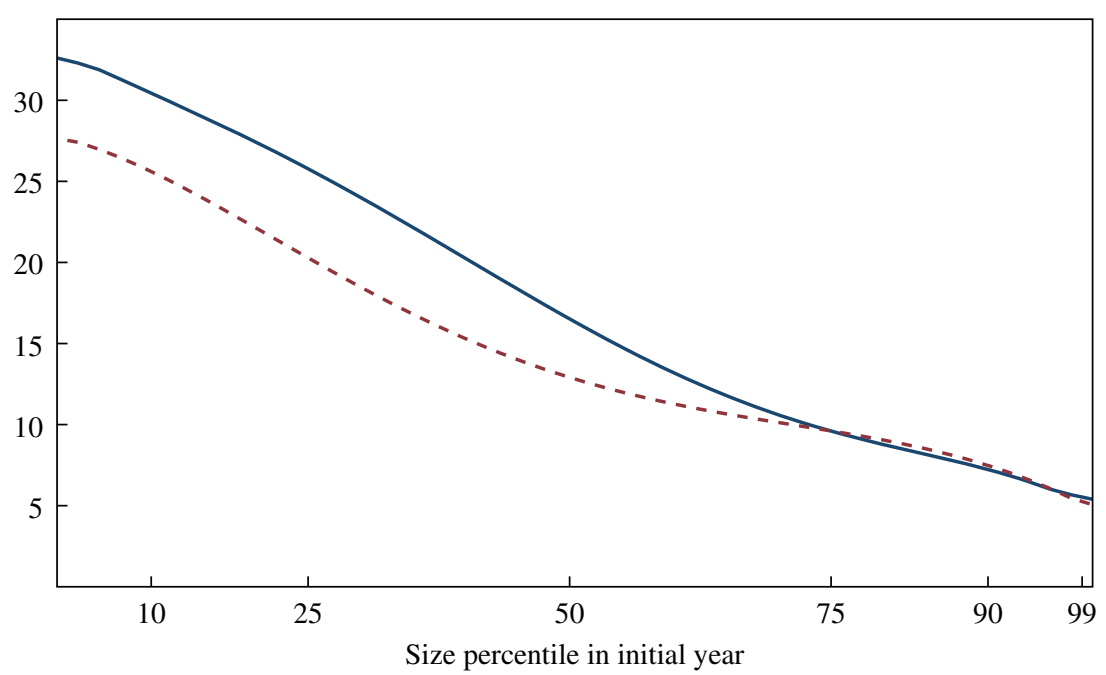

Source: Authors' calculations, based on microdata from China's Industrial Survey.

a. Based on ownership in 1998; size is value added in 1998

b. Based on ownership in 2007; size is value added in 2007 . 
Table 4. Firm Characteristics by Ownership, 1998a

(Weighted mean relative to surviving private firms)

\begin{tabular}{lccc}
\hline & Value-added $^{\text {b }}$ & Value-added/worker $^{\mathrm{c}}$ & Value-added/capital $^{\text {d }}$ \\
\hline State-owned in 1998 & & & \\
Exit by 2007 & -0.830 & -1.155 & -1.250 \\
& $(0.013)$ & $(0.009)$ & $(0.011)$ \\
Privatized by 2007 & 0.288 & -0.536 & -0.870 \\
& $(0.021)$ & $(0.015)$ & $(0.018)$ \\
State-owned in 2007 & 1.128 & -0.518 & -1.060 \\
& $(0.017)$ & $(0.012)$ & $(0.014)$ \\
Private in 1998 & & & 0.107 \\
Exit by 2007 & -0.578 & -0.191 & $(0.010)$ \\
& $(0.012)$ & $(0.009)$ &
\end{tabular}

Source: Authors' calculations, based on microdata from China's Industrial Survey.

a. The reference group in each column is private firms in 1998 that survived until 2007. All observations are weighted by employment. Standard errors are in parentheses.

b. Value added is log value added,

c. Value added/worker is log value added per worker.

d. Value added/capital is log value added per unit of capital.

higher than those of comparably sized private firms over the same period, but the difference is not as large as in the earlier period (1998 to 2007).

Table 4 quantifies the characteristics of state-owned firms in 1998 (relative to private firms that survived until 2007). Comparing the first row (exiting state-owned firms) with the third row (surviving state-owned firms), we can see that value added, labor productivity, and capital productivity are generally lower among exiting state-owned firms than among surviving state-owned firms. These patterns are roughly consistent with the goal implicit in the slogan "Let Go of the Small," although the implementation seems far from perfect. Many small state-owned firms were not closed and some large state-owned firms were closed.

SURVIVORS We now turn to the balanced panel of firms between 1998 and 2007 and between 2007 and 2012. We focus on three groups of surviving firms in the two balanced panels: state-owned, privatized state-owned, and private firms.

We begin with the balanced panel of firms between 1998 and 2007. Figure 4 plots the fraction of the state-owned firms that were privatized over the two time periods. Specifically, figure 4 plots the annual average over each time period of the fraction of state-owned firms that were privatized from 1998 to 2007 (top panel) and from 2007 to 2012 (bottom panel) in bins defined by percentiles of the firms' value added in 1998 (top panel) and 
Figure 4. Annual Privatization Rate of State-Owned Firms, 1998-2007 and 2007-12

1998-2007

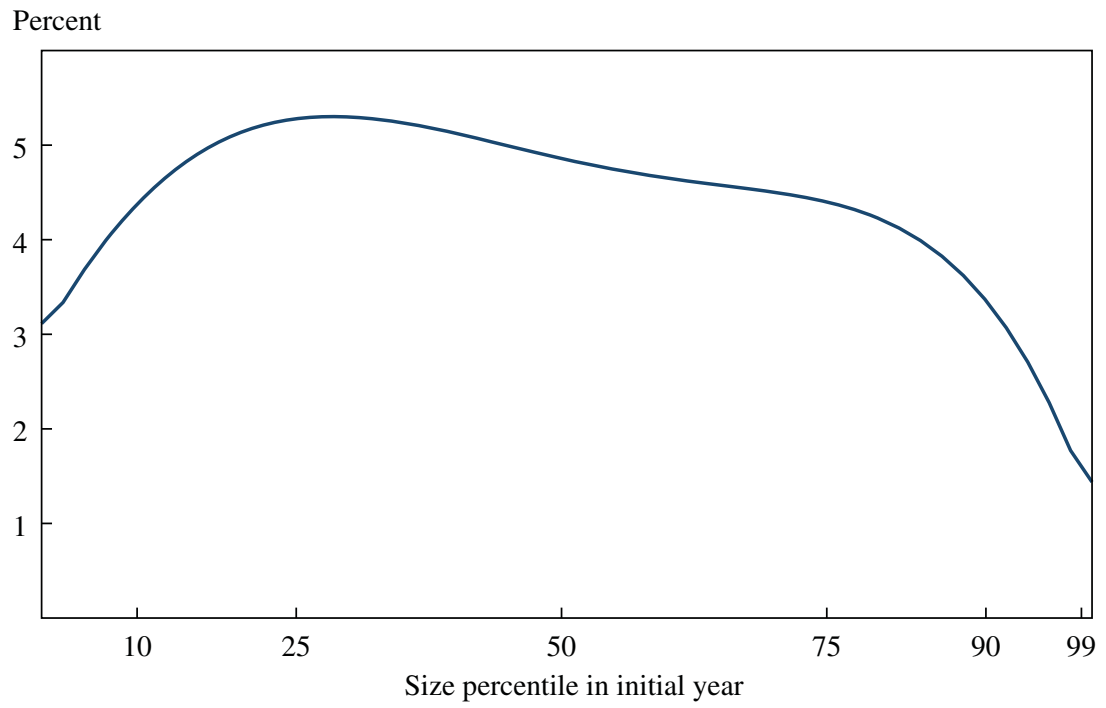

2007-12

Percent

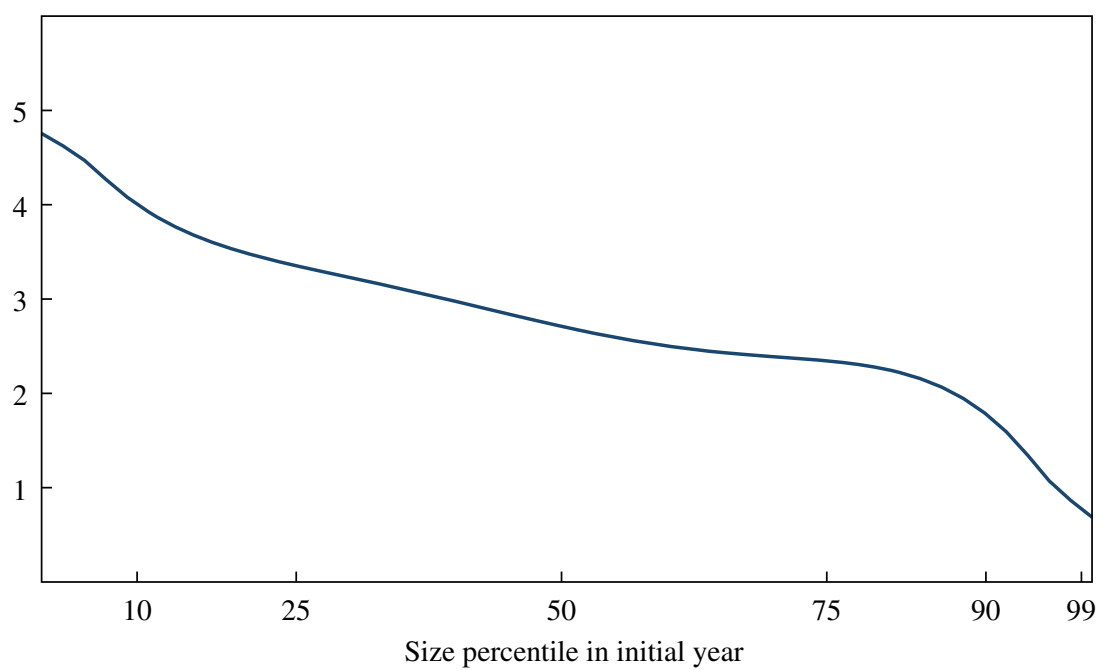

Source: Authors' calculations, based on microdata from China's Industrial Survey.

a. Number of state-owned firms in 1998 that were private in 2007 relative to the number of state-owned firms in 1998 that survived until 2007 (including state-owned firms in 1998 that were privatized by 2007) divided by nine (number of years between 1998 and 2007). Size is value added in 1998.

b. Number of state-owned firms in 2007 that were private in 2012 relative to the number of state-owned firms in 2007 that survived until 2012 divided by five (number of years between 2007 and 2012). Size is value added in 2007. 
2007 (bottom panel). From 1998 to 2007, there is an inverse U-shaped relationship between the probability of privatization and the initial size of the state-owned firms in 1998. Although the goal was that small state-owned firms were to be closed or privatized ("let go"), many of the smallest stateowned firms were kept under state control. From 1998 to 2007, only 30 to 35 percent of the surviving state-owned firms in the bottom decile of the size distribution were privatized. The privatization rate is highest among midsized state-owned firms and lowest among the largest state-owned firms, which is consistent with the officially stated goal that large firms were to be kept under state control ("grasped" by the Chinese state). But again, implementation was highly imperfect, as many small state-owned firms were not privatized or closed.

The pattern of privatization from 2007 to 2012 is different in two respects. First, the overall privatization rate is lower than from 1998 to 2007. Second, there is no longer the inverse $U$ shape seen in the earlier period. The probability of privatization after 2007 strictly decreases according to the initial size of the state-owned firms in 2007.

Figure 5 presents the distribution of employment by value added among state-owned (top panel) and privatized firms (bottom panel) in 1998 and 2007. The size distribution of state-owned and privatized firms shifted slightly to the left from 1998 to 2007, relative to the value added of private firms in each year. Furthermore, the change in size distribution is similar for state-owned and privatized firms.

Figure 6 plots the corresponding distribution of employment by labor productivity (value added/employment) in 1998 and 2007. The figure shows that the labor productivity of the two groups of state-owned firms was significantly lower than that of private firms in 1998. The difference in 1998 was about 40 percent (table 4). By 2007, the gap in labor productivity had narrowed significantly, about equally for firms that remained under state control and those that were privatized by 2007 . Table 4 quantifies the characteristics of state owned firms in 2007 relative to incumbent private firms (firms that were also in operation in 1998). The difference in labor productivity between the two groups of firms narrowed between 1998 and 2007, rising from about 60 percent of the labor productivity of private firms in 1998 to 75 percent in 2007.

Figure 7 plots the distribution of capital productivity (value added/ capital). The capital productivity of state-owned firms is also significantly lower than that of private firms in 1998. Table 4 indicates that the average capital productivity of state-owned firms was about 35 percent of that of private firms in 1998. By 2007, the gap in capital productivity had 
Figure 5. Value Added of State-Owned and Privatized Firms, 1998 and 2007

\section{State-owned firms}

Density of employment

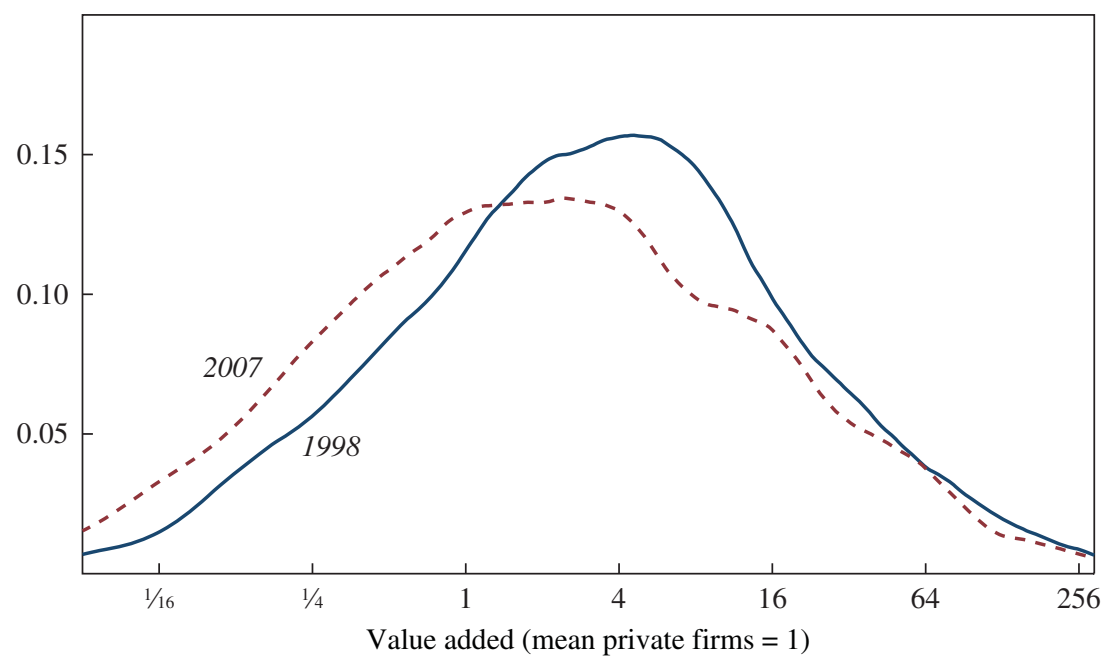

Privatized state-owned firms

Density of employment

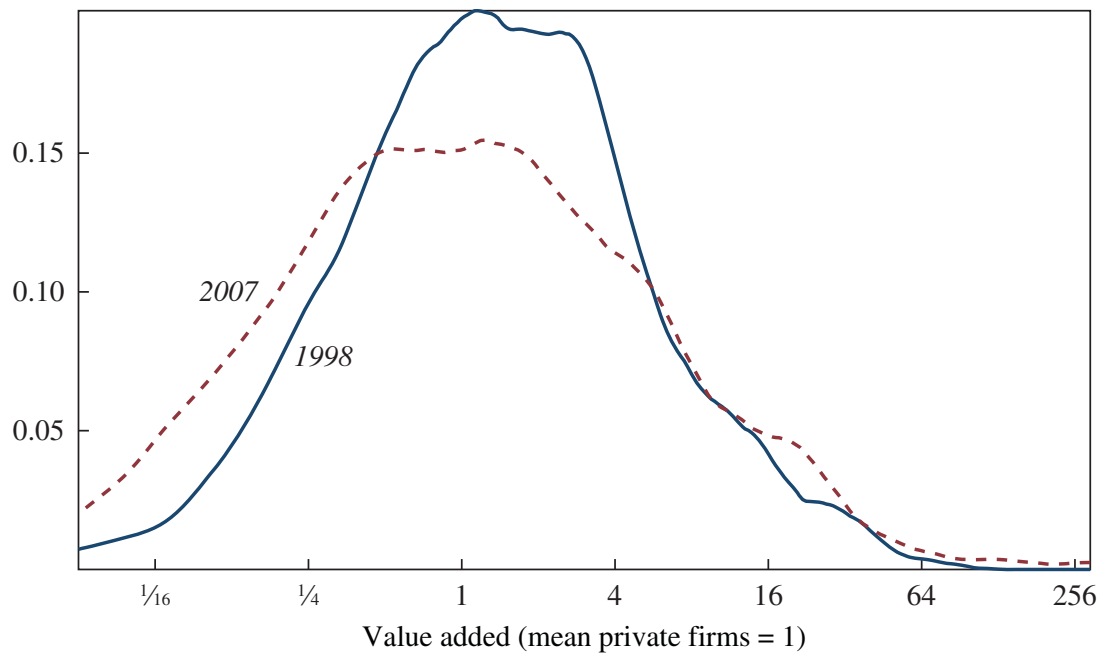

Source: Authors' calculations, based on microdata from China's Industrial Survey.

a. Sample is the balanced panel from 1998 to 2007. Size is measured by firm value added normalized by mean of value added of private firms in each year. Observation for each firm is weighted by employment.

b. State-owned firms are state-owned in 1998 and 2007.

c. Privatized firms are state-owned in 1998 and privately owned in 2007. 
Figure 6. Labor Productivity of State-Owned and Privatized Firms, 1998 and 2007a

\section{State-owned firms}

Density of employment

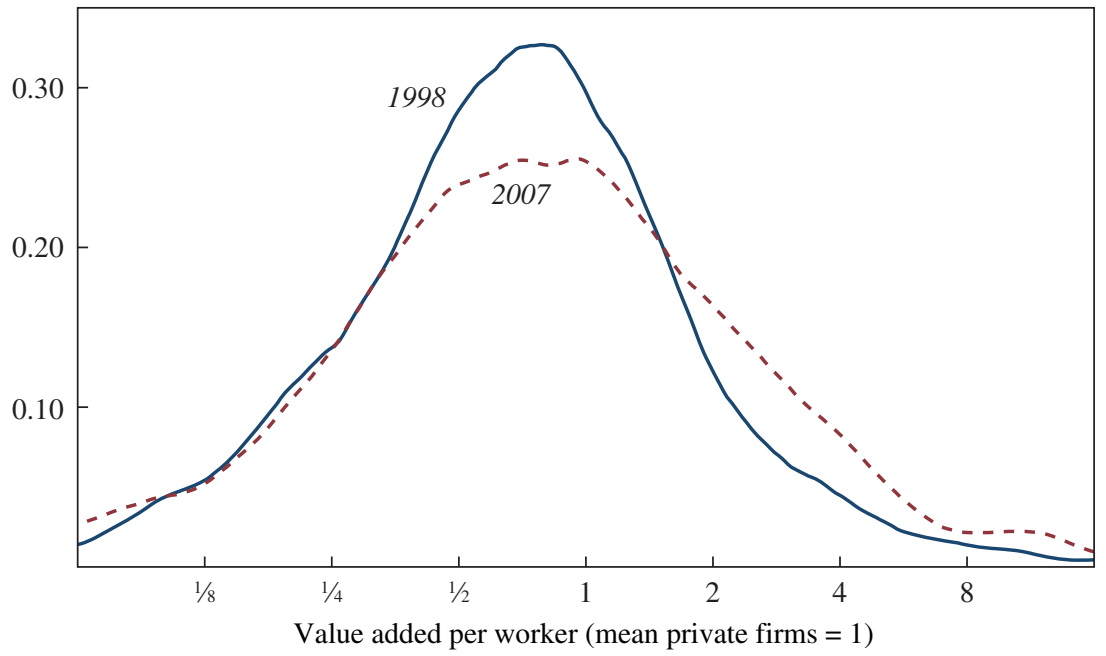

Privatized state-owned firms

Density of employment

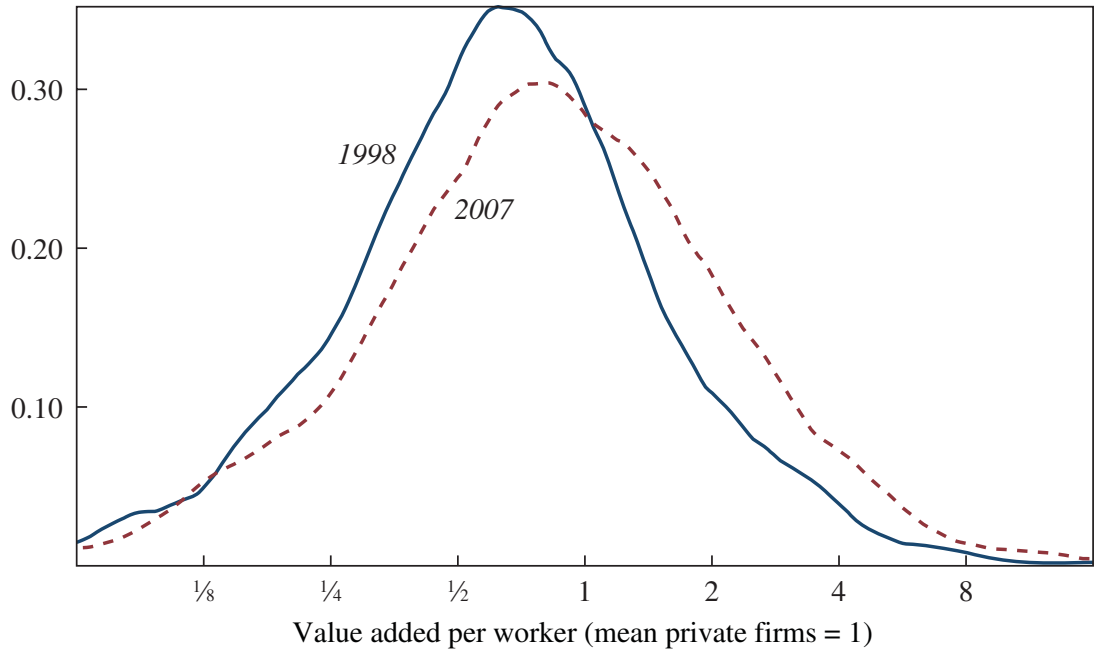

Source: Authors' calculations, based on microdata from China's Industrial Survey

a. Sample is the balanced panel from 1998 to 2007. Labor productivity is normalized by employment weighted mean of labor productivity of surviving private firms in each year. Observation for each firm is weighted by firm employment. See figure 5 notes for definition of state-owned and privatized state-owned firms. 
Figure 7. Capital Productivity of State-Owned and Privatized Firms, 1998 and 2007

\section{State-owned firms}

Density of employment

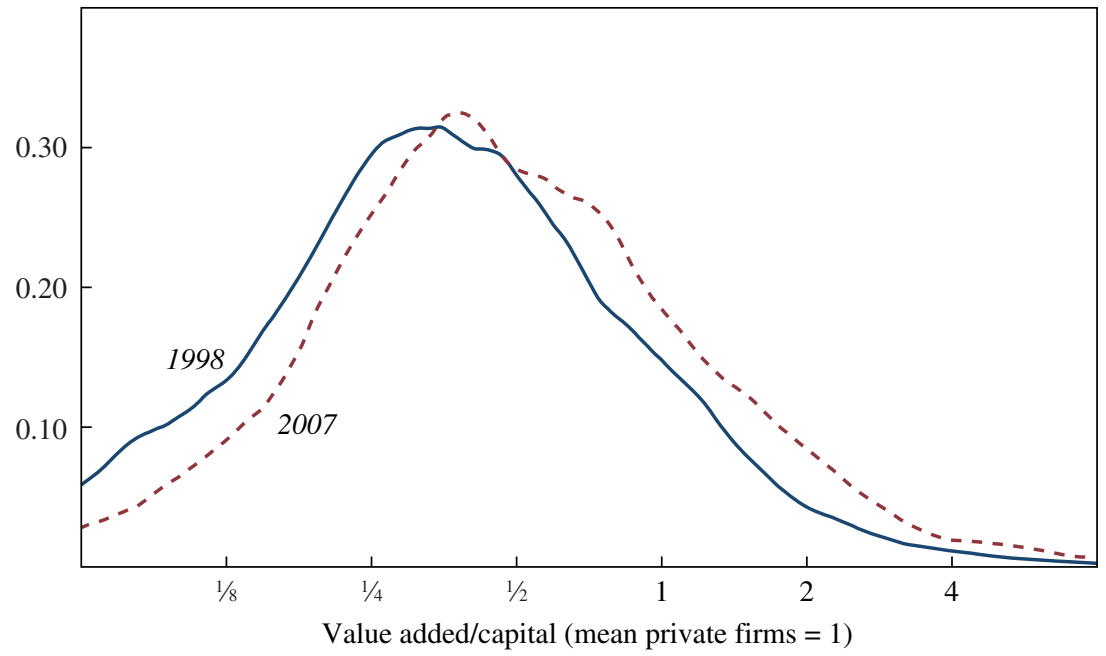

Privatized state-owned firms

Density of employment

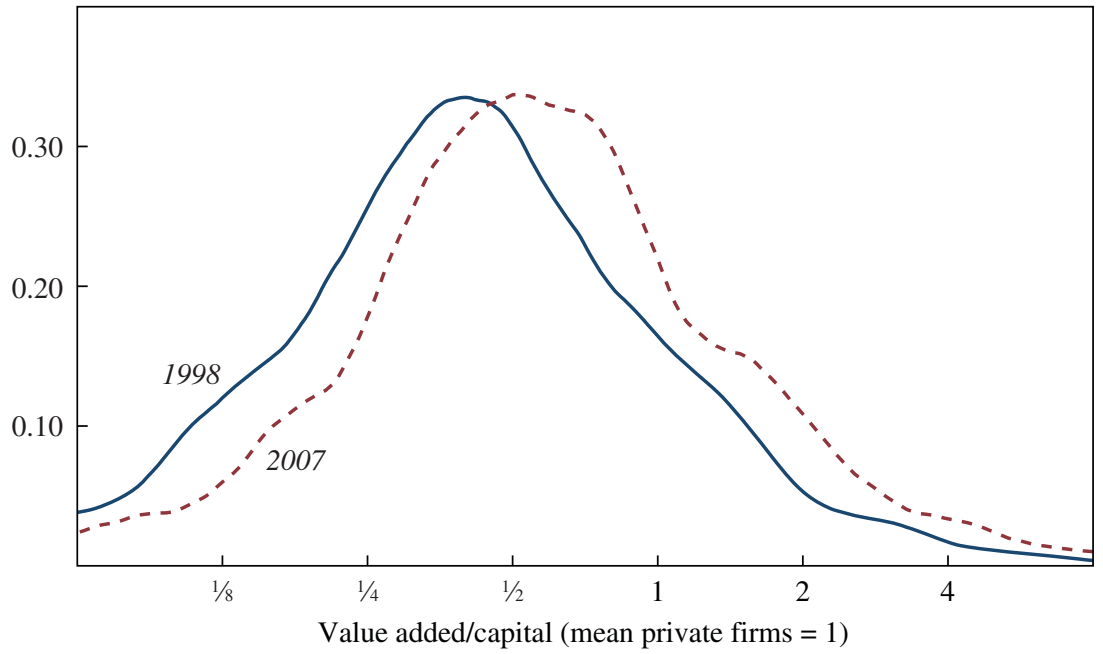

Source: Authors' calculations, based on microdata from China's Industrial Survey.

a. Sample is the balanced panel from 1998 to 2007. Labor productivity is normalized by employment weighted mean of labor productivity of surviving private firms in each year. Observation for each firm is weighted by firm employment. See figure 5 notes for definition of state-owned and privatized state-owned firms. 
Table 5. Firm Characteristics by Ownership, 2007ª

(Weighted mean relative to surviving private firms)

\begin{tabular}{lccc}
\hline & Value added $^{\text {b }}$ & Value added/worker $^{\mathrm{c}}$ & Value added/capital $^{\text {d }}$ \\
\hline State-owned in 2007 & & & \\
$\quad$ Entrant & 0.526 & 0.107 & -0.282 \\
& $(0.022)$ & $(0.015)$ & $(0.016)$ \\
State-owned in 1998 & 0.812 & -0.322 & -0.751 \\
& $(0.015)$ & $(0.010)$ & $(0.012)$ \\
Private in 2007 & & & \\
$\quad$ Entrant & -1.035 & -0.065 & 0.460 \\
& $(0.009)$ & $(0.006)$ & $(0.007)$ \\
State-owned in 1998 & -0.003 & -0.278 & -0.557 \\
& $(0.020)$ & $(0.013)$ & $(0.015)$ \\
\hline
\end{tabular}

Source: Authors' calculations, based on microdata from China's Industrial Survey.

a. The reference group is surviving private firms in 2007 (that also existed in 1998). All observations are weighted by employment. Entrants are firms established after 1998. Standard errors are in parentheses.

b. Value added is log value added.

c. Value added/worker is log value added per worker.

d. Value added/capital is log value added per unit of capital.

narrowed slightly: capital productivity of state-owned firms was then about 47 percent of that of private firms (table 5). And, perhaps surprisingly, there was still a significant gap in capital productivity between privatized and private firms in 2007.

The fact that the size distribution of state-owned and privatized firms shifted to the left suggests that the effects may have been different for small compared with large state-owned firms. When we look explicitly at growth rates for firms of different sizes (based on their size in 1998), we find that state-owned firms that were small (large) in 1998 grew at a slower (faster) rate compared to private firms with the same initial size. The heterogeneity across the size distribution carries over when we look at relative labor productivity growth but is less pronounced for the relative capital productivity growth. This evidence suggests that despite the government's goal of converting surviving state-owned firms into profit-maximizing firms, among those that remained under state control this may have only happened among the larger state-owned firms.

We end this section by showing the changes in revenues, labor productivity, and capital productivity among state-owned firms operating in 2007 and in 2012. The main limitation is that the 2012 data do not include firm value added or the net book value of the capital stock. In the absence of these data, we measure firm size by revenues, labor productivity as the ratio of revenues to employment, and capital productivity as the ratio of revenues 
to the gross book value of the capital stock. We present the distribution of revenues, labor productivity, and capital productivity of state-owned firms in 2007 and 2012 in figure 8 (normalized by the relevant statistic of incumbent private firms). To be clear, the sample is the balanced panel of firms that were operating and state-owned during those two years. As can be seen in the top panel, relative size of incumbent state-owned firms was roughly the same in 2012 compared to 2007. The middle panel shows that average labor productivity of the state-owned firms continued to increase from 2007 to 2012 relative to incumbent private firms, albeit at a lower rate than in the 1998 to 2007 period. Finally, the bottom panel shows that there is little convergence in capital productivity after 2007.

ENTRANTS We now turn to entrants. In the 1998-2007 panel, entrants are defined as firms created after 1998. Table 1 indicates that such entrants account for about a third of the state-owned firms in 2007. In terms of employment, state-owned entrants account for more than 20 percent of total employment of state-owned firms in 2007. Figure 9 plots the distribution of value added (top panel), labor productivity (middle panel), and capital productivity (bottom panel) of state-owned entrants and private entrants. As before, we normalize by the corresponding statistic for surviving private firms. The top panel shows that new state-owned firms are significantly larger than new private firms. The middle panel shows that the labor productivity of new state-owned firms and new private firms is about the same as that of surviving private firms. The bottom panel shows that the capital productivity of new state-owned firms is lower than that of surviving private firms, while the capital productivity of new private firms is about the same.

Table 2 indicates that state-owned entrants in 2012 (defined as stateowned firms created after 2007) account for about 10 percent of employment among state-owned firms in 2012. On an annualized basis, the entry rate of state-owned firms is only slightly lower in 2007-12 compared to the entry rate in $1998-2007 .{ }^{16}$ Figure 10 plots the distribution of revenues (top panel), labor productivity (middle panel), and capital productivity (bottom panel) of new state-owned firms and private firms in 2012. As in 2007, the labor productivity of new state-owned firms is about the same as in new private firms and capital productivity is lower in new state-owned firms. What is different is that new state-owned firms are now much bigger relative to new private firms (compared to 2007).

16. 10 percent over 5 years $=2$ percent per year in $2007-12$, whereas 21 percent over 9 years $=2.3$ percent per year in 1998-2007. 
Figure 8. Size and Productivity of State-Owned Firms, 2007 and 2012

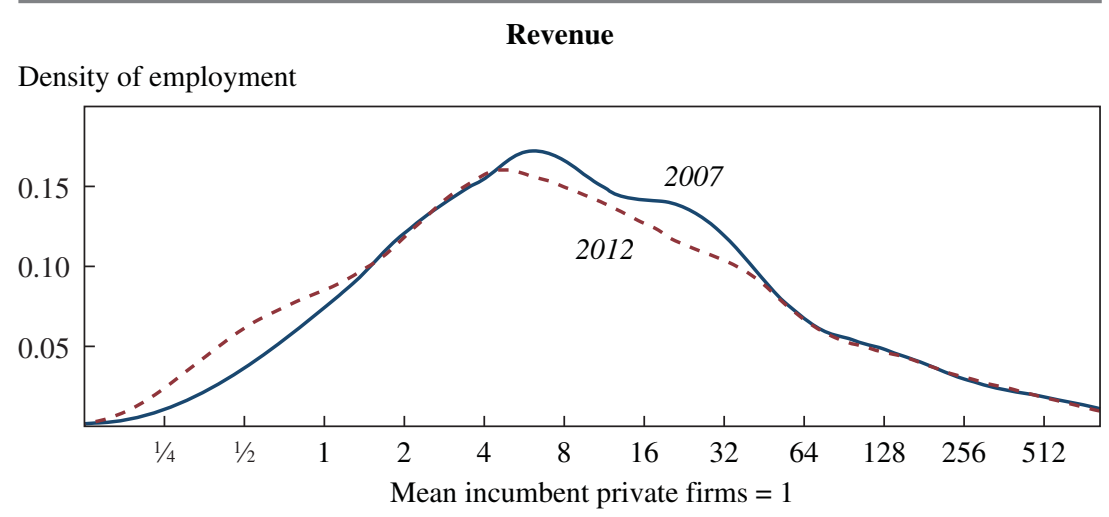

Labor productivity (revenue/worker)

Density of employment

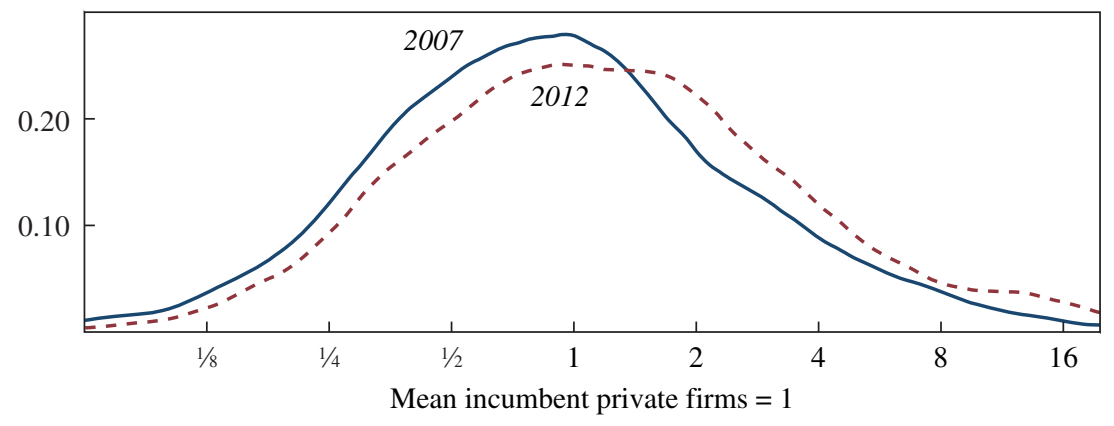

Capital productivity (revenue/capital)

Density of employment

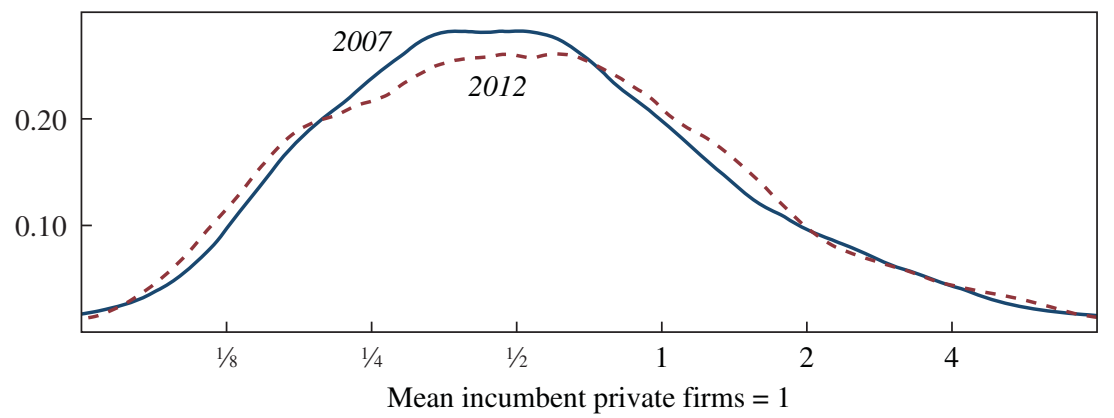

Source: Authors' calculations, based on microdata from China's Industrial Survey.

a. Sample is firms in 2007 established after 1998. Observations are weighted by employment and normalized by weighted mean of incumbent private firms in 2007 . 
Figure 9. Size and Productivity of Entrants in 2007

\section{Size (value added)}

Density of employment

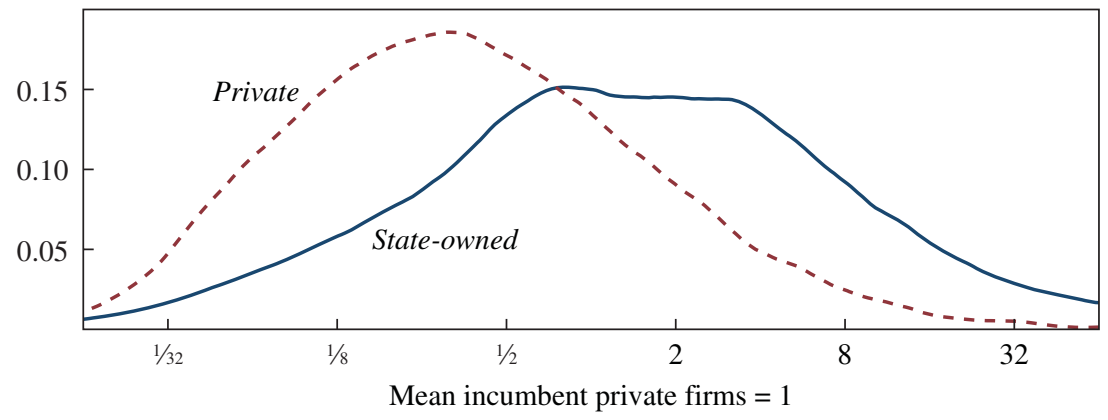

Labor productivity (value added/worker)

Density of employment

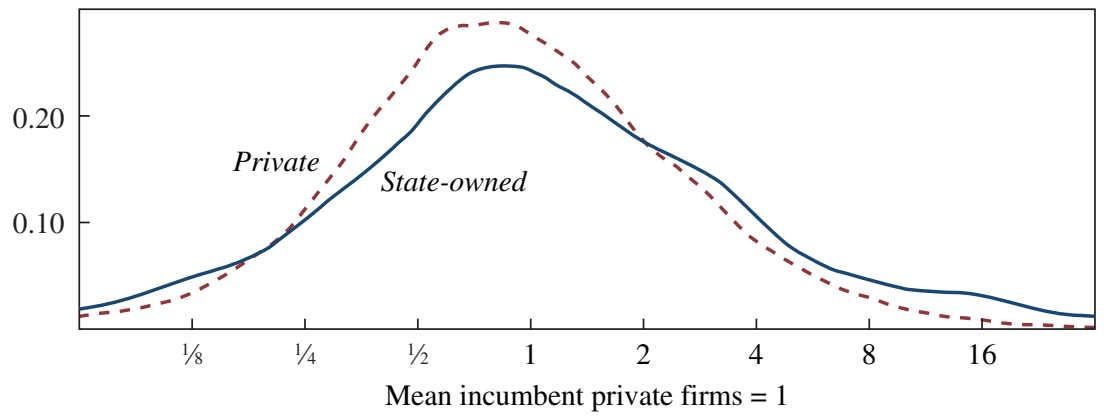

Capital productivity (value added/capital)

Density of employment

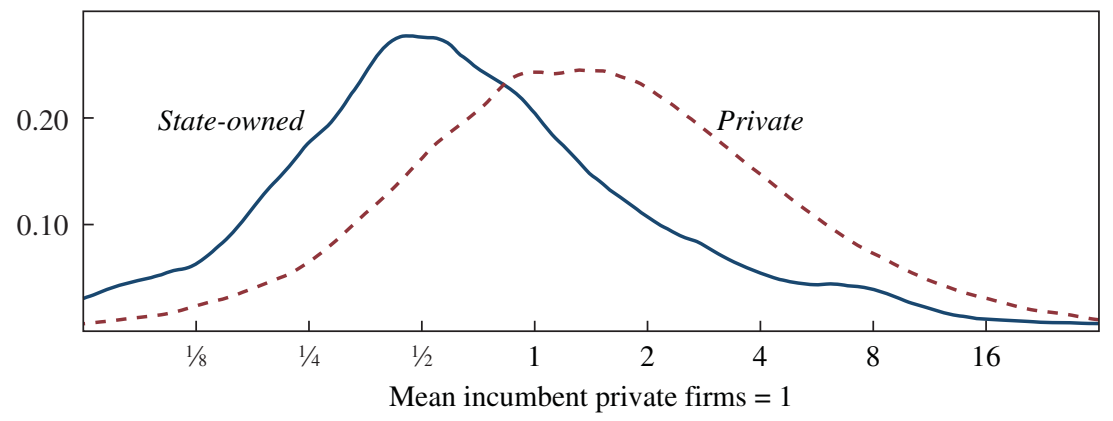

Source: Authors' calculations, based on microdata from China's Industrial Survey.

a. Sample is the balanced panel of state-owned firms from 2007 to 2012. Observation for each firm is weighted by employment and normalized by weighted mean of surviving private firms in each year. State-owned firms are state-owned in 2007 and 2012. 
Figure 10. Size and Productivity of Entrants in 2012a

\section{Revenue}

Density of employment

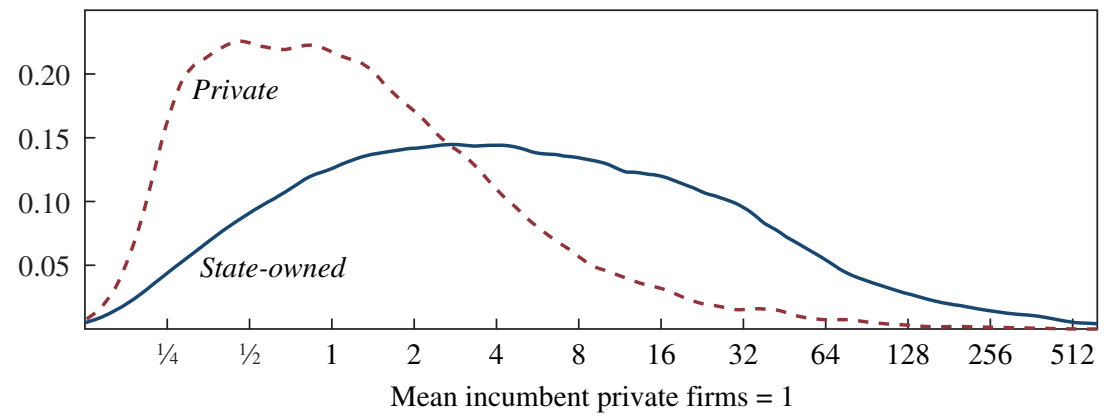

Revenue/worker

Density of employment

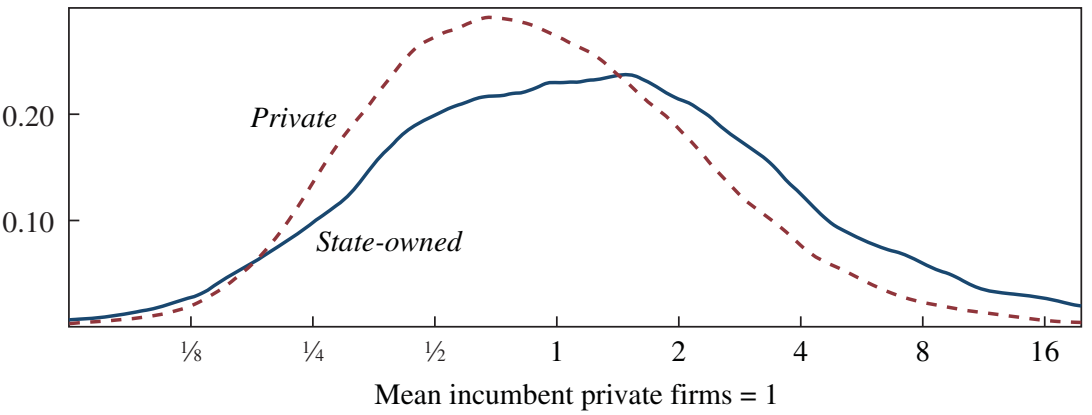

Revenue/capital

Density of employment

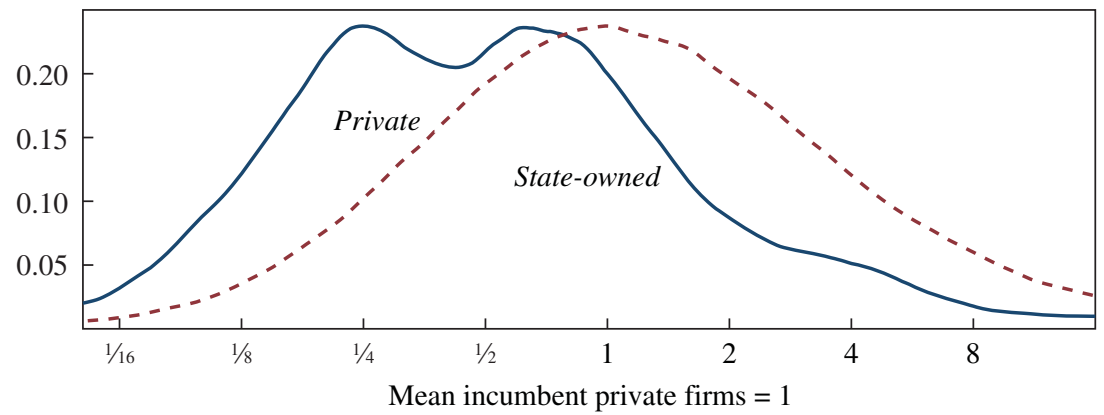

Source: Authors' calculations, based on microdata from China's Industrial Survey.

a. Sample is firms in 2012 established after 2007. Observations are weighted by employment and normalized by weighted mean of surviving private firms in 2012 . 


\section{I.D. Main Facts}

The main facts may be summarized as follows.

Exit rates: Exit rates increased after 1998 among state-owned firms, particularly for small state-owned firms.

Privatization: Large state-owned firms were kept mostly under state control, but the smallest state-owned firms that survived were also kept under state ownership. Midsized state-owned firms were the most likely to be privatized from 1998 to 2007 . After 2007, privatization rates declined on average but increased for small state-owned firms.

State-owned vs. privatized firms: The performance of the average stateowned firm is similar to that of the average privatized firm. For both groups of firms, from 1998 to 2007, the labor productivity gap with surviving private firms narrowed significantly and the capital productivity gap narrowed by much less. Capital productivity was still less than 50 percent of that of private firms. The growth of labor productivity of state-owned firms relative to that of private firms slowed down after 2007. There was little convergence in capital productivity from 2007 to 2012.

Small vs. large state-owned firms: The labor productivity gap with surviving private firms narrowed significantly between 1998 and 2007 for large state-owned firms and widened for small state-owned firms.

New state-owned firms: Many new state-owned firms were established after 1998. New state-owned firms are larger, have the same labor productivity, and have lower capital productivity compared to new private firms.

\section{A Model-Based Accounting Framework}

This section presents a standard model of heterogeneous firms with monopolistic competition. We use this framework to quantify the effect of the different forces behind China's growth. Aggregate output is a constantelasticity-of-substitution (CES) aggregate of the output of individual firms,

$$
Q=\left(\sum_{i}^{N} Q_{i}^{1-\eta}\right)^{\frac{1}{1-\eta}}
$$

Here, $i$ indexes the firm; $N$ is the number of firms; $Q_{i}$ is firm output; and $1 / \eta>1$ is the elasticity of substitution between varieties. Firm output is given by

$$
Q_{i}=A_{i} K_{i}^{\alpha} L_{i}^{1-\alpha},
$$

where $A_{i}$ denotes firm-specific total factor productivity (TFP). 
Each firm chooses factor inputs, output, and revenue to maximize current profits

$$
\pi_{i}=P_{i} Q_{i}-\left(1+\tau_{i}^{L}\right) w L_{i}-\left(1+\tau_{i}^{K}\right) r K_{i},
$$

where $P_{i}$ is the firm-specific output price; $L_{i}$ and $K_{i}$ denote labor and capital inputs; $w$ and $r$ denote the common undistorted cost of labor and capital; and $\tau^{L}{ }_{i}$ and $\tau^{K}{ }_{i}$ denote firm-specific distortions to the cost of labor and capital. To be clear, we do not believe that $\tau^{L}{ }_{i}$ and $\tau^{K}{ }_{i}$ are necessarily explicit taxes or subsidies. Rather, they are a stand-in for a variety of departures from standard competitive markets, such as preferential access to capital for certain types of firms or political pressures to maintain employment within state-owned firms.

Profit maximization yields these standard first-order conditions:

$$
\begin{gathered}
M P L_{i} \equiv(1-\alpha)(1-\eta) \frac{P_{i} Q_{i}}{L_{i}}=\left(1+\tau_{i}^{L}\right) w, \\
M P K_{i} \equiv \alpha(1-\eta) \frac{P_{i} Q_{i}}{K_{i}}=\left(1+\tau_{i}^{K}\right) r .
\end{gathered}
$$

This says that the values of the marginal product of labor $\left(M P L_{i}\right)$ and the marginal product of capital $\left(M P K_{i}\right)$ are proportional to average labor productivity and capital productivity, respectively. Crucial to this result is the assumption of common markups and capital elasticities. Furthermore, marginal and average products of labor and capital are higher in firms with higher labor and capital costs, as represented by $\tau_{i}^{L}$ and $\tau_{i}^{K}$.

Equilibrium allocations are as follows:

$$
\begin{gathered}
P_{i} Q_{i} \propto\left(\frac{A_{i}}{\left(1+\tau_{i}^{K}\right)^{\alpha}\left(1+\tau_{i}^{L}\right)^{1-\alpha}}\right)^{\frac{1-\eta}{\eta}}, \\
L_{i} \propto \frac{1}{1+\tau_{i}^{L}}\left(\frac{A_{i}}{\left(1+\tau_{i}^{K}\right)^{\alpha}\left(1+\tau_{i}^{L}\right)^{1-\alpha}}\right)^{\frac{1-\eta}{\eta}}, \\
K_{i} \propto \frac{1}{1+\tau_{i}^{K}}\left(\frac{A_{i}}{\left(1+\tau_{i}^{K}\right)^{\alpha}\left(1+\tau_{i}^{L}\right)^{1-\alpha}}\right)^{\frac{1-\eta}{\eta}} .
\end{gathered}
$$


It is useful to combine equations 3, 4, and 5 to express firm revenue in terms of variables that can be measured in the data:

$$
P_{i} Q_{i} \propto\left[\frac{A_{i}}{\left(\frac{P_{i} Q_{i}}{L_{i}}\right)^{\alpha}\left(\frac{P_{i} Q_{i}}{K_{i}}\right)^{1-\alpha}}\right]^{\frac{1-\eta}{\eta}} .
$$

This says firm revenue is increasing in $A_{i}$ and decreasing in average labor and capital productivity. Intuitively, the firms with high labor and capital productivity are the ones with high marginal products of labor and capital, which reduce input demand and firm size (holding $A_{i}$ fixed).

Equation 3 interprets low average product of labor as reflecting low marginal product of labor. However, consider a production function that incorporates overhead labor, $f_{i}$ :

$$
Q_{i}=A_{i} K_{i}^{\alpha}\left(L_{i}-f_{i}\right)^{1-\alpha} .
$$

Here, $f_{i}$ has a straightforward interpretation for state-owned firms: It represents the redundant workers who produce zero marginal product but cannot be fired. With overhead labor, the marginal product of labor is no longer proportional to the average product of labor. We denote $\hat{\tau}_{i}^{L}$ as the distortions that affect MPL, while $\tau_{i}^{L}$ still stands for the distortions that affect labor productivity. To see the relationship between the two distortions, the firstorder condition for labor can be expressed this way:

$$
\frac{P_{i} Q_{i}}{L_{i}} \propto 1+\tau_{i}^{L}=\left(1-\frac{f_{i}}{L_{i}}\right)\left(1+\hat{\tau}_{i}^{L}\right) .
$$

The gap in the average product of labor, as represented by $\tau_{i}^{L}$, can be decomposed into two components: $f_{i}$ and $\hat{\tau}_{i}^{L}$. A reduction in $f_{i}$ will not affect the marginal product of labor but will increase the average product. In what follows, we will note wherever the distinction matters between the marginal-product and the overhead-cost interpretations of the average product.

To close the model, we assume labor supply is fixed (and normalized to one). In addition, we assume $r$ is exogenous and given by the world interest 
rate. We later consider an alternative where the supply of capital in China is fixed.

After we impose profit maximization and market clearing, aggregate output is

$$
Y=\left(N^{\frac{\eta}{1-\eta}} A^{*} Z\right)^{\frac{1}{1-\alpha}}
$$

where

$$
\begin{aligned}
A^{*} & \equiv\left(\frac{1}{N} \sum_{i} A_{i}^{\frac{1-\eta}{\eta}}\right)^{\frac{\eta}{1-\eta}}, \\
Z & \equiv\left[\sum\left(\frac{\overline{M P}}{M P_{i}}\right)^{\frac{1-\eta}{\eta}} Y_{i}^{*}\right]^{\frac{\eta}{1-\eta}}, \\
Y_{i}^{*} & \equiv \frac{1}{N}\left(\frac{A_{i}}{A^{*}}\right)^{\frac{1-\eta}{\eta}}, \\
M P_{i} & \equiv M P K_{i}^{\alpha} M P L_{i}^{1-\alpha}, \\
\overline{M P} & \equiv r^{\alpha} \overline{M P L}{ }^{1-\alpha},
\end{aligned}
$$

and $\overline{M P L}$ denotes the average marginal product of labor.

The first term, $N^{\frac{\eta}{1-\eta}}$, in equation 11 is the standard variety effect. More entry and less exit, all else equal, will increase aggregate output. The second term, $A^{*}$, is a harmonic mean of firm TFP and reflects the direct effect of firm TFP. The third term, $Z$, measures the effect of resource misallocation: more dispersed marginal products across firms, all else equal, lower the aggregate output. This term equals one when the marginal product of labor and capital is the same across firms. The exponent, $1 / 1-\alpha$, measures the effect of endogenous capital accumulation. If we drop the assumption that the cost of capital is exogenous and, instead, assume a fixed supply of capital, this effect would not be there and the exponent would be one.

To see the effect of entry and exit on aggregate growth between times $t$ and $t+1$, we group firms into those that exit after year $t$, those that enter between $t$ and $t+1$, and incumbent firms that exist during the two years, and we denote each group by these subscripts: exit for the exiting firms, ent 
for the entering firms, and inc for the incumbent firms. The ratio of aggregate output at time $t+1$ to aggregate output at time $t$ is:

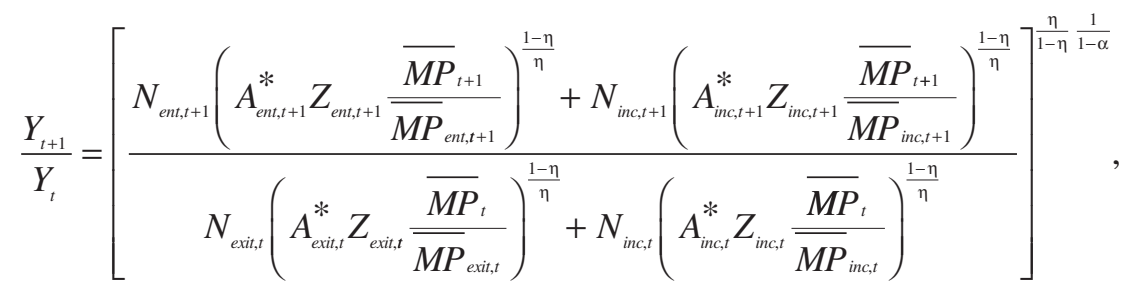

Here, $A^{*}$ is a harmonic mean of firm TFP and $N$ the number of firms of each group (exiters, entrants, and incumbents), $Z$ is the index of allocative efficiency within each group of firms, and $\overline{M P}$ denotes the weighted average of the marginal product of each group. We can use equation 12 to map the effect of entry and exit of state-owned firms on aggregate growth.

The effect of exit on aggregate productivity growth can be seen by adding $N_{\text {exit }}\left(A_{\text {exit }}^{*} Z_{\text {exit }} \overline{M P} / \overline{M P}_{\text {exit }}\right)^{\frac{1-\eta}{\eta}}$ to $Y_{t+1}$, as if the exiters survived at $t+1$. There are two main effects. First, exit implies a loss of varieties, and the effect on aggregate output is given by the product of the number of exiting firms $N_{\text {exit }}$ and the productivity of the average exiting firm $A_{\text {exit }}^{*}$.

Second, exit may also affect overall allocative efficiency. The term $Z_{\text {exit }}$ captures the allocative efficiency among exiters. The effect on the allocative efficiency between exiters and incumbents is captured by $\overline{M P} / \overline{M P}_{\text {exi }}$, which measures the gap between the marginal product among exiters and the average marginal product among all firms in the economy. If the marginal product of resources used by the exiting firm is equal to the average marginal product, then the envelope theorem applies and there is no net welfare gain from the reallocation of resources. In that case, the effect of exit on aggregate output is unambiguously negative. However, if the marginal product of exiting firms is lower than the average marginal productwhen $\overline{M P} / \overline{M P}_{\text {exit }}>1$-then the reallocation of resources from exiting firms increases $M P$ and therefore increases aggregate output. The net effect on aggregate output depends on whether the gain from reallocation exceeds the direct effect of the loss of productive firms.

The mechanisms by which entry affects aggregate growth are similar. Here, the effect of entrants is captured by $N_{\text {ent, }, t+1}\left(A_{\text {ent } t+1}^{*} Z_{\text {ent }, t+1} \overline{M P}_{t+1} / \overline{M P}_{\text {ent }, t+1}\right)^{\frac{1-\eta}{\eta}}$. First, the direct effect of entry on aggregate growth is given by $N_{e n t} A_{e n t}^{*}$. More entry, and entry of more productive firms, increases aggregate 
output. In addition, there can be general equilibrium effects on other firms depending on the gap between the marginal product of entrants relative to the average, which is captured by $\overline{M P}_{t+1} / \overline{M P}_{\text {ent } t+1+}$. When the marginal product of entrants is the same as that of other firms, the envelope theorem applies again and there is no additional effect of entry. However, when the marginal product of entrants exceeds the average-when $\overline{M P} / \overline{M P}_{\text {ent }}<1-$ the reallocation of resources toward entrants improves overall resource allocation, which increases aggregate output.

We can also use equation 12 to analyze the effect of incumbent firms on aggregate growth. The effect of incumbent firms on aggregate output growth is given by $N_{i n c, t+1}\left(A_{i n c, t+1}^{*} Z_{i n c, t+1} \overline{M P}_{t+1} \overline{M P}_{i n c, t+1}\right)^{\frac{1-\eta}{\eta}}$. For instance, privatization of state-owned firms may improve firm TFP, and the effect on aggregate output is given by

$$
\frac{\partial Y}{\partial A_{i}}=\frac{1}{1-\alpha}[\underbrace{\frac{Y_{i}}{A_{i}}}_{\text {the direct effect }}+\underbrace{\frac{1}{\eta} \frac{L_{i}}{A_{i}}\left(M P L_{i}-\overline{M P L}\right)}_{\text {the reallocation effect }}] .
$$

The first term of equation 13 captures the effect of $A_{i}$ on the productivity of the representative firm, holding the efficiency of resource allocation fixed. We think of this as the direct effect of TFP. The second term measures the effect of higher firm TFP on the efficiency of resource allocation. The reallocation effect is negative if the firm's MPL is below the average MPL, and it is positive otherwise. Intuitively, labor is reallocated to firms with higher TFP. This reallocation has no effects on allocative efficiency if the firm's marginal product of labor is the same as that of other firms. This would be the case if the average product of labor of the firm that experiences TFP growth is the same as the average, or if the gap in the average product of labor entirely reflects overhead costs rather than differences in the marginal cost of labor. However, if the marginal product of labor in the firm is lower than the average, higher TFP increases employment in the low-marginalproduct firm, which worsens the overall efficiency of resource allocation. If the gap in marginal products is sufficiently large, the negative reallocation effect can dominate the technological effect. Specifically, equation 13 can be expressed as:

$$
\frac{\partial Y}{\partial A_{i}}=\frac{1}{1-\alpha} \frac{1}{\chi \eta} \frac{L_{i}}{A_{i}}\left(M P L_{i}-\chi \overline{M P L}\right),
$$


where $\chi \equiv \frac{(1-\eta)(1-\alpha)}{1-\alpha(1-\eta)}<1$. If $M P L_{i}<\chi \overline{M P L}$, an increase in the firm's TFP will lower aggregate output. Whether higher TFP increases or lowers aggregate output depends on the gap between the firm's MPL and the average marginal product (and the value of $\chi$ ).

Privatization may also change the gap in the average product of capital and labor of the privatized firms (relative to the other firms). In equation 12 this is captured by the change in $\overline{M P} / \overline{M P}_{\text {inc }}$. For example, if state-owned firms had been forced to employ more workers than necessary, the average product of labor of state-owned firms could decline after they were privatized and no longer faced political constraints to keep unproductive workers on the payroll. Similarly, privatized state-owned firms might no longer have preferential access to capital, which is modeled here as a decline in $\tau_{i}^{K}$. The effect of a change in the gap in MPL relative to the average on aggregate output is given by

$$
\frac{\partial Y}{\partial \tau_{i}^{L}}=-\frac{1-\alpha}{\chi \eta} \frac{L_{i}}{1+\tau_{i}^{L}}\left(M P L_{i}-\overline{M P L}\right)
$$

This says that a narrowing of the gap between a firm's average product of labor and the overall average product of labor always increases aggregate output. Although equation 15 assumes that the change in the average product of labor is driven by a change in marginal labor costs, the effect on aggregate output would be the same if the change in the average product of labor were driven by the elimination of redundant labor in state-owned firms. Similarly, the effect on aggregate output of a change in a given firm's MPK follows:

$$
\frac{\partial Y}{\partial \tau_{i}^{K}}=-\frac{\alpha}{\chi \eta} \frac{L_{i}}{1+\tau_{i}^{K}}\left(M P L_{i}-\chi \overline{M P L}\right) .
$$

The reason this looks different from the effect of changes in MPL is the assumption that capital is available elastically at world interest rates. A decline in MPK of a firm is like a positive TFP shock, and the TFP shock can have a negative effect on aggregate output if it significantly worsens the allocation of labor.

The "corporatization" of state-owned firms could have two effects on aggregate output. First, firm TFP could increase, although the effect of an improvement in firm TFP on aggregate output is ambiguous and would 
depend on whether the direct effect of higher TFP exceeded the effect of changes in resource allocation. Second, state-owned firms could increase their average product of labor by shedding surplus labor, which would unambiguously increase aggregate output.

In this paper, we use equation 12 to measure the effect on aggregate output of three forces: (i) exit and privatization of state-owned firms; (ii) "corporatization" of incumbent state-owned firms; and (iii) entry of new state-owned firms. To be sure, these three forces will only explain (in a proximate sense) a fraction of the aggregate output growth in China's industrial sector. The residual is aggregate growth driven by the private sector.

Measuring the components of this residual is beyond the scope of this paper, but equation 12 also lays out what these components might be. First, there is the effect of the entry of new private firms, an effect that is increasing in both the number and the productivity of the new private firms. Second, there is the direct effect of the productivity growth of incumbent private firms. Third, if the marginal product of private firms is higher than that of state firms, private entry and productivity growth will have the additional effect of improving the allocation of resources. Fourth and finally, private sector growth can also be driven by an improvement in the efficiency of resource allocation within private firms (such as due to an overall improvement in the efficiency of capital markets).

Finally, it is useful to compare the data-inference exercise based on equation 12 with a commonly used accounting decomposition of aggregate growth. There are many variants of this decomposition, but a common one decomposes growth in aggregate output per worker into growth due to reallocation toward firms with high output per worker and growth in output per worker within each group of firms. ${ }^{17}$ The former is interpreted as the gain from reallocation, and the latter as firm TFP growth. Specifically, in a model where labor is the only factor of production, aggregate growth in output per worker $y$ is given by

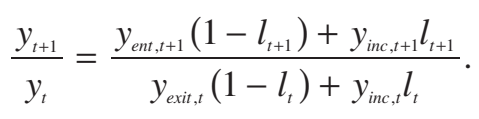

As before, the subscripts ent, exit, and inc refer to entrants, exiters, and incumbents, and $l$ refers to the employment share of incumbent firms.

17. This decomposition was first used by Baily, Hulten, and Campbell (1992). See Brandt, Van Biesebroeck, and Zhang (2012) for an application of this decomposition to productivity growth in China. 
Equation 17 suggests the following inferences from the microdata. First, reallocation increases aggregate output when the employment share of high $y$ firms increases, and it decreases aggregate output otherwise. For example, firm exit increases aggregate output only if the output per worker of exiting firms is lower than that of incumbent firms. Among incumbent firms, an increase in the employment share of private firms raises aggregate output if the output per worker of private firms is higher than that of stateowned firms. Second, the change in output per worker of a group of firms (such as incumbent firms, state-owned firms, or private firms) would be interpreted as the result of TFP growth. For example, if output per worker growth is higher among private firms compared to state-owned firms, then TFP growth must have been higher among private firms compared to stateowned firms.

The inferences based on equation 12 differ in both aspects. First, the equation also indicates that reallocation toward high $y$ firms or sectors increases aggregate output, but for a different reason. In the equilibrium model of heterogeneous firms, such reallocation increases aggregate output by lowering the dispersion in the marginal product of resources across firms and not by increasing the employment share of high TFP firms. In fact, an increase in the employment share of high TFP firms could lower output if the marginal product of resources of high TFP firms were low. Second, we interpret an increase in $y$ of a given group of firms as reflecting either an increase in the marginal product or as an elimination of redundant labor and not necessarily as evidence of increases in TFP.

These differences stem from the different assumptions underlying the two approaches. The accounting approach assumes that differences in $y$ across firms reflect firm TFP and is unclear about what exactly drives differences in the employment share. Our approach assumes that differences in $y$ only reflect differences in the marginal product of labor, while differences in TFP across firms show up as differences in the employment share.

Ultimately the validity of any approach depends on whether the assumptions are reasonable. Equation 12 is based on a specific equilibrium model of heterogeneous firms. Some of the assumptions (common factor elasticities and markups across firms, for example) may be unrealistic, but we can assess whether the results are sensitive to alternative assumptions (see Song and $\mathrm{Wu}$ 2014). A decomposition based on equation 17 may also provide the correct answers, but to our knowledge the precise assumptions behind this approach, such as what determines the equilibrium allocation of resources between firms and the conditions under which differences in $y$ reflect differences in firm TFP, have never been spelled out. Understanding 
the conditions under which inferences based on equation 17 are correct is an important task that we leave for future work.

\section{Productivity and Distortions of State-Owned and Privatized Firms}

We now interpret the facts presented in section I through the lens of the model in section II. We apply the model to each industry and then aggregate industry output into aggregate output. To capture the industry effects, we allow $\delta, w$, and $\alpha$ to be industry-specific. We also assume the labor force to be fixed in an industry. ${ }^{18}$

We begin with the differences in labor productivity between state and private firms. According to equation 3, differences in the average product of labor reflect differences in the marginal revenue product of labor. The convergence in labor productivity from 1998 to 2007 between state-owned and private firms shown in figure 6 indicates that the marginal product of labor in state-owned firms converged to that of private firms over this time period. ${ }^{19}$ Similarly, equation 4 indicates that the gap in the average product of capital between state-owned and privatized firms relative to private firms reflects differences in the marginal product of capital. Therefore, the evidence in figures 7 and 8 indicates that the marginal product of capital in state-owned firms was lower than that of private firms, and that much of this gap was still present in 2007 and 2012. Furthermore, there is little difference in average product of labor and capital between state-owned firms that remained under state control and those that were privatized. In particular, the marginal product of capital of the privatized firms in 2007 was almost the same as that of the state-owned firms, as if the privatized firms continued to have access to capital on the same terms as the state-owned firms. And among the new state-owned firms, figures 9 and 10 indicate the average product of labor is similar to that of private firms, but the average product of capital is substantially lower.

The fact that the average product of capital is lower among state-owned and privatized state-owned firms, and has remained low, is not surprising if the low average product of capital reflects low marginal product of capital. In turn, the low marginal product of capital may reflect preferential access

18. We can generate a fixed labor supply in an industry by assuming that aggregate output is a Cobb-Douglas aggregate of aggregate industry output.

19. See also Kamal and Lovely (2013) for the convergence of the average product of labor between state and private firms. 
to capital among state-owned and privatized firms. Preferential access to capital increases the profits of firms with access. Under this interpretation, it appears that formerly state-owned firms, even after they are privatized, continue to benefit from preferential access to capital.

In contrast to the patterns in capital productivity, there is significant convergence of labor productivity between state-owned and private firms. We see this among the surviving state-owned firms, among the newly established state-owned firms, and even among the privatized state-owned firms. This finding is hard to interpret if lower labor productivity reflects a lower marginal cost of labor, but it is easy to interpret if state-owned firms had a substantial amount of redundant labor. The fact that the average product of labor is lower among state-owned firms in 1998 could be due to overstaffing in these firms. ${ }^{20}$ The political pressure to employ redundant workers declined after 1998, as state-owned firms became corporatized and presumably were incentivized to maximize profits. In our data, employment in the surviving state-owned firms declined by 3.6 million workers from 1998 to 2007, about 40 percent of their initial employment. We do not know how many of these workers were redundant workers, but note that a decline in the number of redundant workers will show up as a decline in the average product of labor and in the labor share. Specifically, we can rewrite equation 10 as follows:

$$
\underbrace{\frac{\left(1+\hat{\tau}_{i}^{L}\right) w L_{i}}{Y_{i}}}_{\text {Labor Share }} \propto \frac{1}{1-f_{i} / L_{i}} .
$$

Equation 18 shows that the labor share falls when $f_{i} / L_{i}$ falls. Figure 11 plots the average labor shares of state-owned, privatized, and private firms in the 1998-2007 balanced panel. ${ }^{21}$

Finally, from equation 8 , firm productivity $A$ can be measured as the residual of firm value added after controlling for the effect of the average product of capital and labor. We use the labor share of private firms in each

20. According to a survey conducted by the Chinese Academy of Social Science in 1995, the narrowly defined redundant workers - that is, those who are idle and have no definite position-accounted for more than 10 percent of total employment in about half of the stateowned firms (Dai 1996).

21. We use value added shares of an industry (averaged over 1998-2007) as the weight to aggregate labor shares. The initial labor shares of state-owned and privatized firms were considerably higher than those of private firms. Moreover, the labor shares of state-owned and privatized firms fell substantially after 1998 . 
Figure 11. Labor Share, $1998-2007^{\text {a }}$

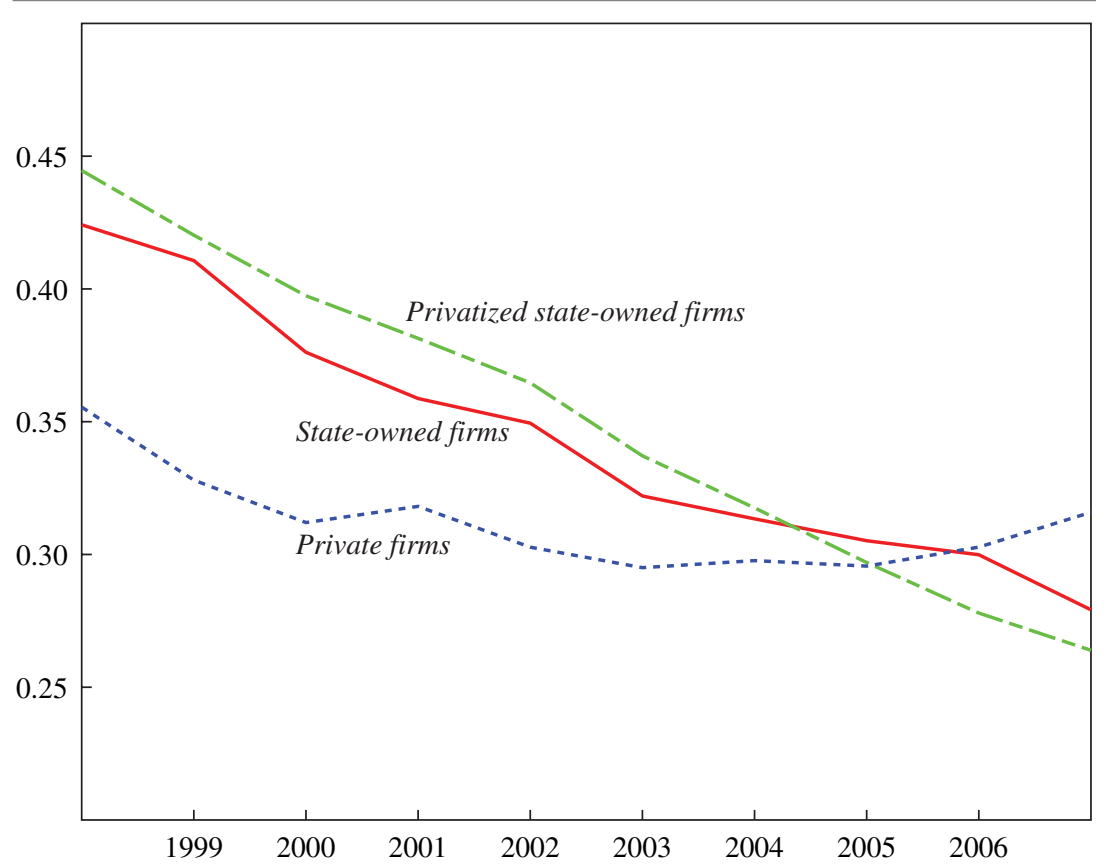

Source: Authors' calculations, based on microdata from China's Industrial Survey.

two-digit industry to measure industry-specific $\alpha$ where we adjust the labor share in each sector such that we match the labor share in China's industrial sector. $^{22}$ We use a baseline value of $1 / \eta=7$, corresponding to a markup of 1.17. ${ }^{23}$ To calculate 2012 firm TFP, we convert revenues to value added by the average industry value added revenue ratios in 2004-07. Firm TFP presented below is scaled by the median TFP of surviving private firms in the same industry. ${ }^{24}$

We find $A$ of exiting state-owned firms to be about half of that of surviving state-owned firms in 1998-2007, while there are no clear differences in $A$ across entrants with different ownership types. Figure 12 plots the

22. See the online appendix. We use the labor share of private firms because distortions may bias the labor share of state-owned firms.

23. We later show the results with different values of $1 / \eta$ as well as allowing markups to differ across state-owned and private firms.

24. We drop industries that have less than ten surviving private firms. The five industries are Extraction of Petroleum and Natural Gas, Mining of Other Ores, Manufacture of Tobacco, Recycling and Disposal of Waste, and Production and Supply of Gas. 
Figure 12. Total Factor Productivity in State-Owned and Privatized Firms, 1998 and $2007^{a}$

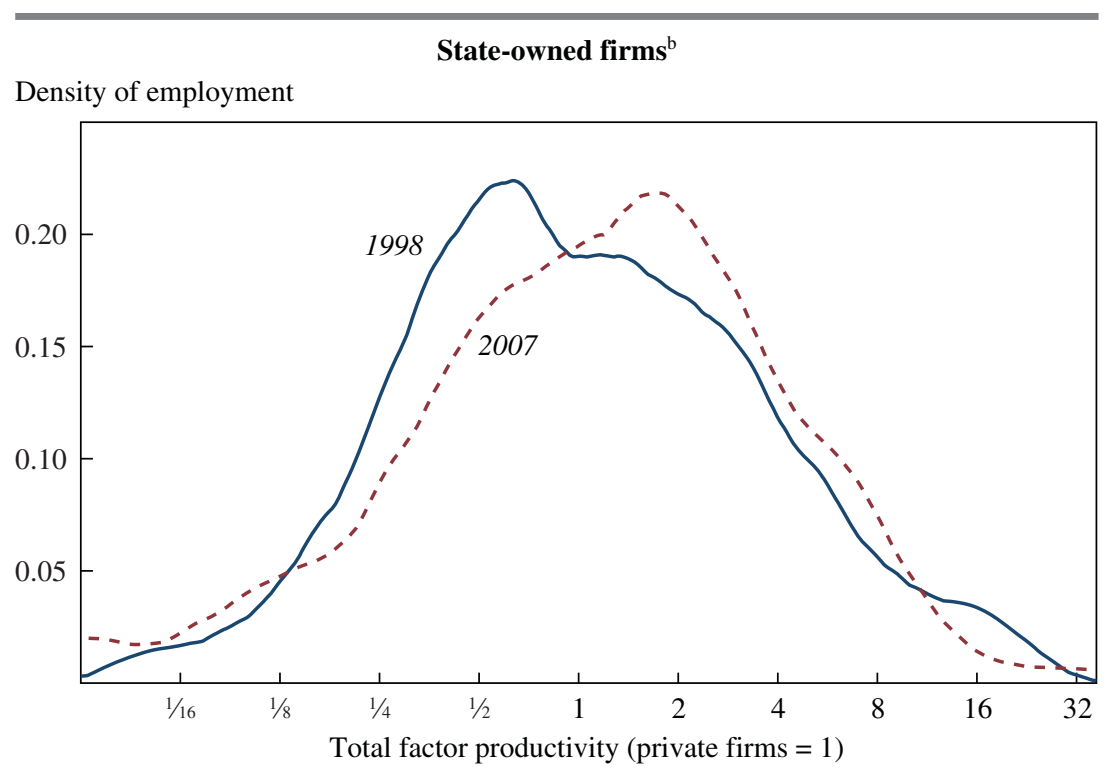

Privatized state-owned firms ${ }^{\mathrm{c}}$

Density of employment

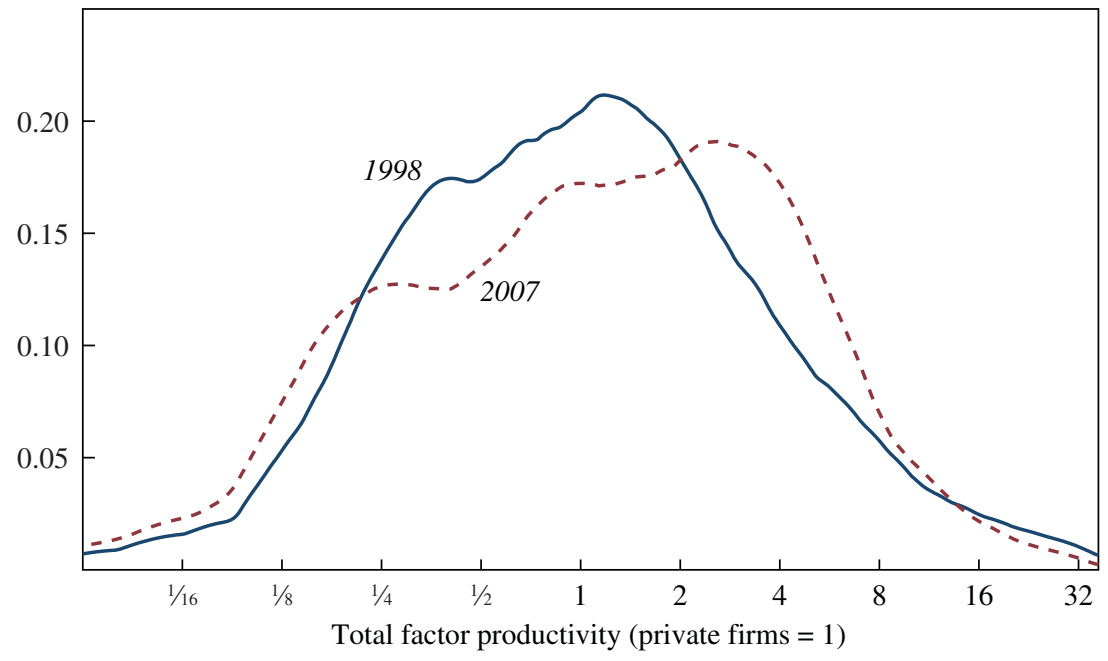

Source: Authors' calculations, based on microdata from China's Industrial Survey.

a. Total factor productivity is normalized by mean of surviving private firms in each year. The sample is the balanced panel from 1998 to 2007.

b. Firms that were state-owned in 1998 and 2007

c. Privatized firms that were state-owned in 1998 and privately owned in 2007. 
resulting distribution of $A$ of state-owned firms (top panel) and privatized firms (bottom panel) in the balanced panel from 1998 to 2007. The top panel indicates that $A$ of state-owned firms was lower than that of private firms in 1998. By 2007, the gap in $A$ between state-owned firms and private firms had narrowed. Similarly, $A$ of privatized firms was lower compared to private firms, but the gap had also declined by 2007. Specifically, the weighted average TFP of surviving state-owned firms relative to that of surviving private firms increased from approximately 55 to 75 percent. The relative TFP of surviving privatized firms increased from approximately 60 to 77 percent.

We next examine heterogeneity in the change in $A$ across the size distribution. The top panel of figure 13 plots the ratio of $A$ of state-owned firms relative to private firms in bins defined by the value added in 1998 (top panel). This figure indicates that $A$ of state-owned firms in the top decile in firm size in 1998 was 30 to 40 percent of that of the privately owned firms of comparable size in 1998. By 2007, among the top decile of state-owned firms, $A$ had increased to about 60 percent of that of the same group of private firms. For small state-owned firms, the pattern is exactly the opposite. In 1998, $A$ of the smallest state-owned firms was 80 to 90 percent of that of private firms of comparable size. By 2007, $A$ among state-owned firms had dropped to about 40 percent of that of the same group of private firms. The bottom panel plots the relative $A$ of the privatized firms. Here, there is less heterogeneity across the size distribution. On average, $A$ of privatized firms grows at faster rates than that of private firms, and this is the case throughout the size distribution. These findings are the mirror images of the facts documented in section I.C.

Finally, subject to the caveats about the limitations of the 2012 data mentioned previously, figure 14 plots the distribution of TFP in a balanced panel of state-owned firms in 2007 and 2012. As can be seen, the figure shows that TFP of state-owned firms continues to grow at a faster rate after 2007 compared to private firms.

In summary, we find high growth rates of TFP and reduction in labor distortions among state-owned and privatized firms since the late 1990s. However, the return to capital continues to be significantly lower among state-owned and privatized firms than among private firms. Large stateowned firms have particularly high growth rates in TFP relative to their private counterparts, but the opposite is true for small state-owned firms.

We end this section with three sets of robustness checks. First, we measure labor input by employment, which implicitly assumes that labor quality is the same across firms. However, the gap in labor productivity 
Figure 13. TFP Growth of State-Owned and Privatized Firms Relative to Private Firms by Initial Size, 1998 and $2007^{a}$

State-owned firms ${ }^{\mathrm{b}}$

Total factor productivity (private firms $=1$ )

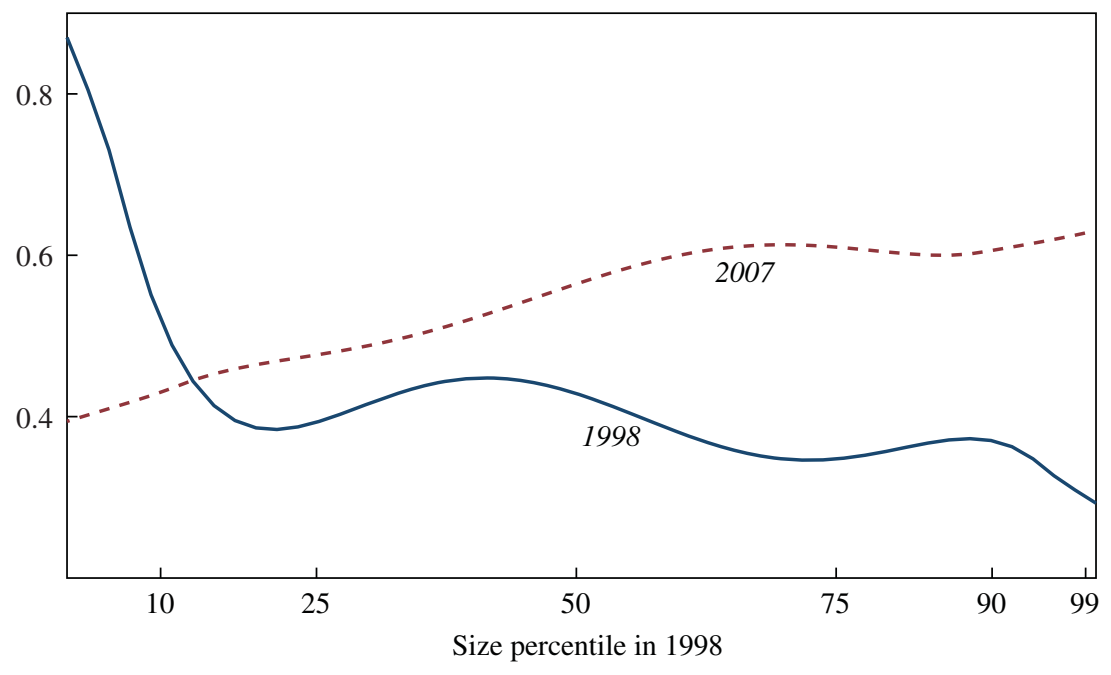

Privatized state-owned firms ${ }^{\mathrm{b}}$

Total factor productivity (private firms $=1$ )

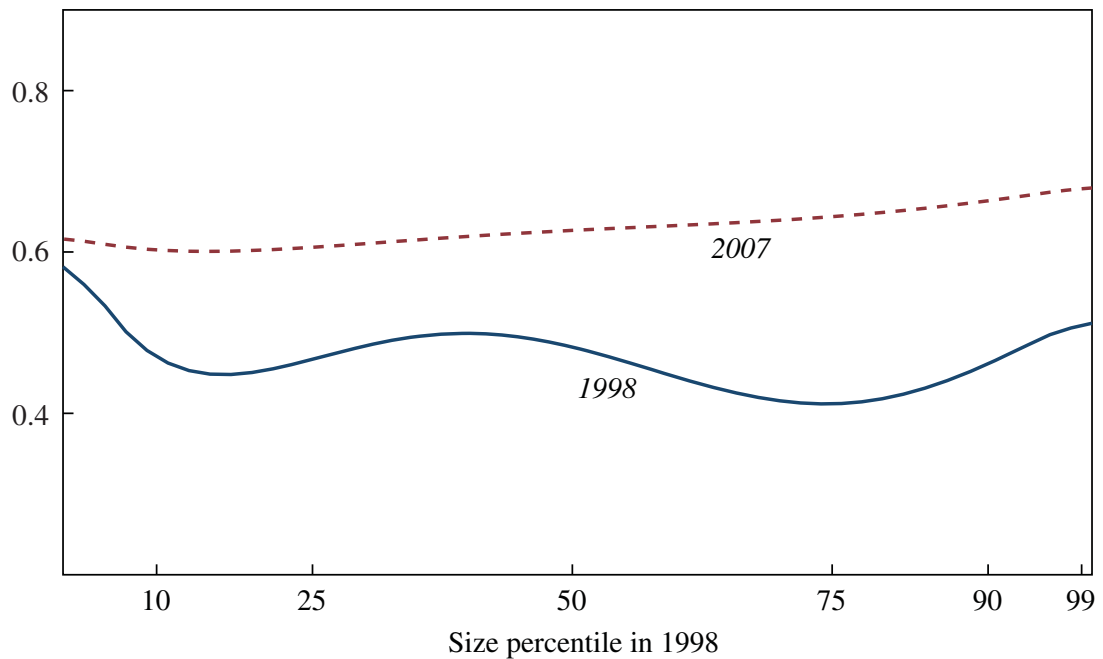

Source: Authors' calculations, based on microdata from China's Industrial Survey.

a. Sample is the balanced panel in 1998 and 2007. TFP in each percentile is normalized by median TFP of surviving private firms in the percentile in each year. Size in 1998 is defined as value added.

b. See figure 12 notes. 
Figure 14. Total Factor Productivity of State-Owned Firms, 2007 and 2012

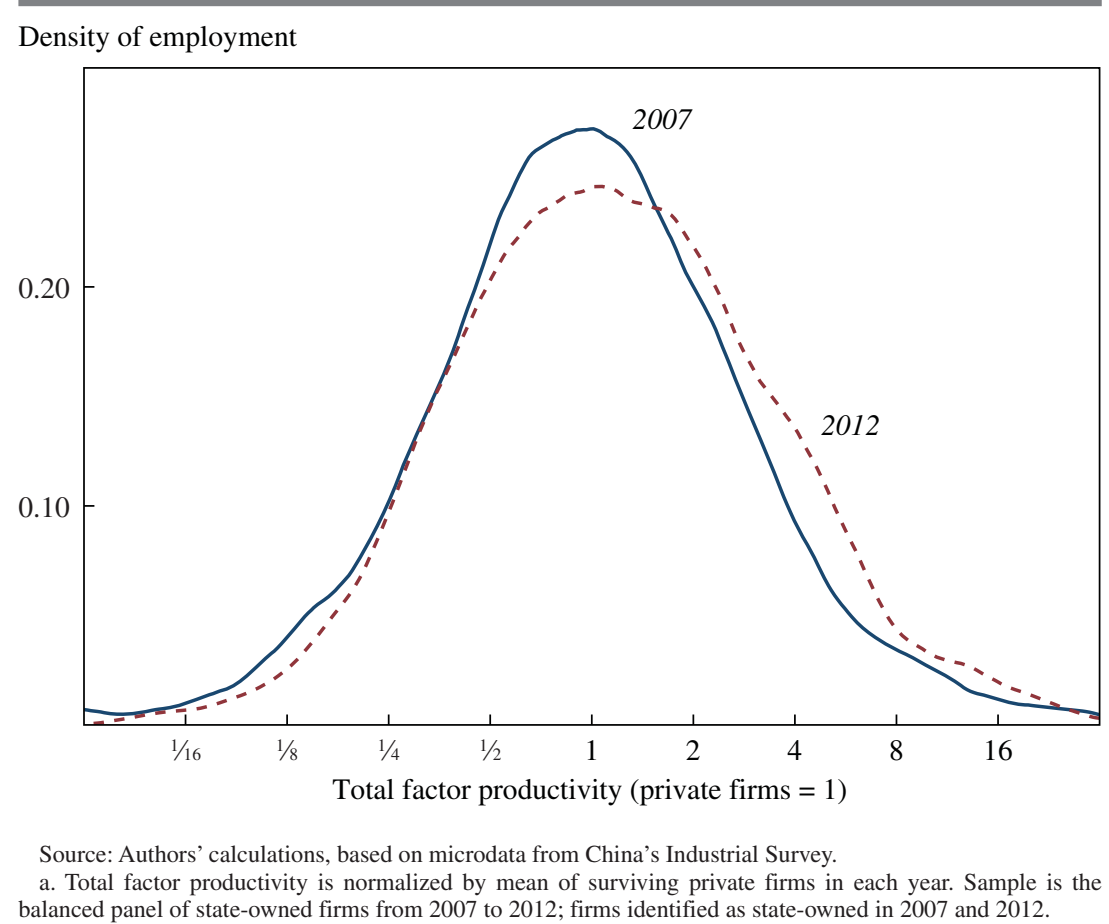

between state and private firms shown in figure 9 may be due to differences in worker quality. To check this, we use data from the 2004 Economic Census to measure the differences in worker quality between state and private firms. The 2004 Census indicates that workers in state-owned firms have, on average, 1.3 more years of schooling than workers in private firms. ${ }^{25}$ When we adjust for the implied gap in worker quality (using estimates of the Mincerian return to schooling), this reduces labor productivity among surviving privatized state-owned firms by about 10 percent. The convergence of labor productivity between state and private firms is not affected, though.

Second, the convergence of TFP is robust to alternative assumptions on markups. Lowering $1 / \eta$ to 3 gives essentially the same relative TFP growth of surviving state-owned firms. Our calculations assume that markups are the same for all firms. We now consider the possibility that

25. The 2004 Economic Census provides data on the educational composition of employment in each firm. See the online appendix. 
state-owned firms have higher markups than private firms. This has two effects on the empirical results. ${ }^{26}$ First, although higher markups among state-owned firms change the implied levels of TFP, $\tau_{i}^{L}$, and $\tau_{i}^{K}$ for these firms, they do not change their implied growth rates. Second, if we assume that markups among privatized state-owned firms decline after becoming privatized, then the implied growth rate of TFP among privatized firms would be higher than shown in figure 10. In addition, the implied reduction in labor and capital distortions among the privatized firms would be larger than shown in figures 6 and 7.

Finally, the evidence presented above suggests that the convergence of labor productivity between state-owned and private firms can be explained by the reduction in the number of surplus workers in the state sector (instead of an increase in the marginal product of labor in state-owned firms). Notice that with the presence of surplus labor, $A_{i}$ has to be adjusted by $f_{i}$.

We consider a scenario in which (i) redundant workers exist only in the firms that are initially state-owned and have labor productivity below the average of surviving private firms in the same industry; and (ii) the labor productivity gap entirely reflects the number of redundant workers. These assumptions are rather extreme, implying massive labor redundancy that accounts for approximately 54 and 35 percent of state employment in 1998 and 2007, respectively. In this scenario, the TFP growth of stateowned firms has to be adjusted downward by falling surplus labor. In the benchmark case, the weighted average TFP of surviving state-owned firms relative to that of surviving private firms grew by approximately 36 percent from 1998 through 2007, while in the scenario adopting the above assumptions on $f_{i}$ the growth would decrease to approximately 26 percent. Despite this, the TFP convergence between state and private firms would remain qualitatively unchanged.

\section{Why Have State-Owned Firms Changed?}

We now turn to institutional forces that may be behind the patterns presented in the last section.

First, governance may have improved among large state-owned firms. Figure 2 shows that almost half of the state-owned firms in 2007 and nearly 60 percent of them in 2012 were legally registered as private firms. For a

26. See the online appendix for details on the model with variable markups, as well as the empirical results. 
subset of these firms for which we can put together detailed ownership information, the typical form this takes is that of state-owned firms "corporatized" with a minority share traded in the stock market and merged into a large state-owned conglomerate. We do not have information on the precise ownership structure of all the firms in the data, but we do know the share of registered capital held by "legal persons." For the sample of state-owned firms for which we have ownership information, the legal person share in the data matches the equity share of the state-owned conglomerate. Figure 15 shows that the average share of registered capital held by legal persons increased dramatically among all state-owned firms after 1998.

Second, there is clear evidence that state-owned firms face greater competition from private firms. Although the goal of the Chinese government was to restrict entry by private firms in the strategic or "pillar" industries, private firms have actually entered in many of the industries where the state has sought to maintain the dominance of state-owned firms. ${ }^{27}$ Table 6 presents the value-added share for state-owned firms in nine such industries (these industries account for about half of China's industrial output) in 1998 and 2007 and the revenue share in 2007 and 2012 (remember that the 2012 data do not report value added, only revenue). Although state-owned firms have a dominant share in most of these industries, the state's share has shrunk in all sectors (except for Electric and Heat Power). Furthermore, the decline of the state share continued after 2007. The decline in the other (nonstrategic) sectors is even more dramatic: The overall value added share of state-owned firms in the industrial sector fell from approximately 55 to 34 percent from 1998 to 2007.

Table 7 examines the correlation of private-sector entry with productivity growth in the state sector across two-digit sectors. We define the private entry rate as the number of new private firms created within a single year relative to the number of all private firms in that year. The private entry rate averaged 7.6 percent in the 1998-2007 period, with a standard deviation of eight percentage points across industries. Column 1 shows that the private-sector entry rate is positively correlated with productivity growth. The effect is independent of ownership.

Third, many of the state-owned firms after 1998 were newly established. As figures 9 and 10 show, these firms were large and also enjoyed preferential access to capital. Such firms may also have provided competition to the surviving state-owned firms. The entry rate of state-owned firms after 1998

27. See the online appendix for details on "strategic" and "pillar" industries. 
Figure 15. State-Owned Firms with "Legal Person" Ownership Share Greater than 50 Percent, 1998-2012a

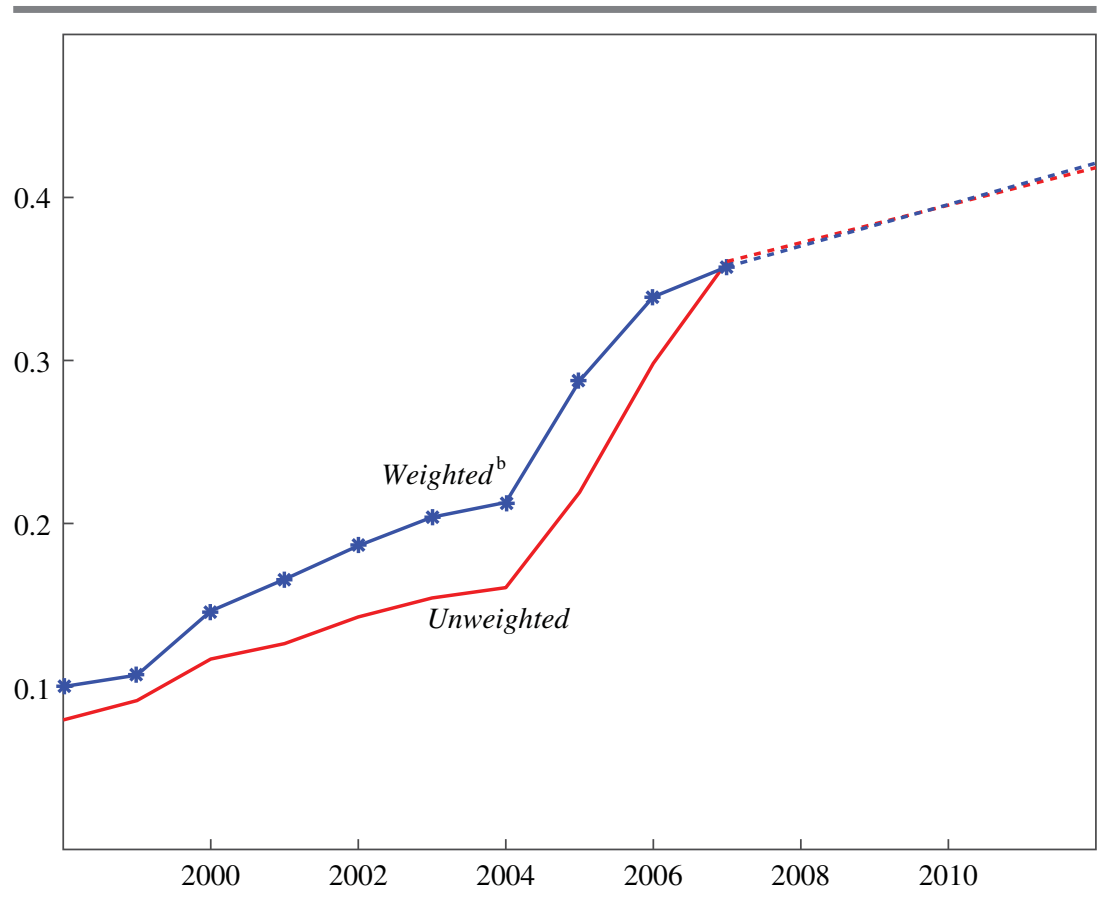

Source: Authors' calculations, based on microdata from China's Industrial Survey.

a. This figure plots the number of state-owned firms with legal person share above or equal to 50 percent as a share of the number of all state-owned firms in each year

b. Weighted by revenue share.

Table 6. Share of State-Owned Firms in Strategic Sectors

Percent

\begin{tabular}{lrrrrr} 
& \multicolumn{2}{c}{ Value-added share } & & \multicolumn{2}{c}{ Revenue share } \\
\cline { 2 - 3 } \cline { 5 - 6 } & 1998 & 2007 & & 2007 & 2012 \\
\hline Mining of coal & 82 & 66 & 66 & 61 \\
Extraction of petroleum & 100 & 97 & 98 & 91 \\
Processing of petroleum & 88 & 63 & 75 & 70 \\
Chemical & 51 & 24 & 27 & 20 \\
Ferrous metals & 79 & 46 & 45 & 37 \\
Nonferrous metals & 54 & 34 & 34 & 36 \\
Transport equipment & 65 & 49 & 51 & 44 \\
Communication equipment & 42 & 8 & 6 & 9 \\
Electric and heat power & 86 & 88 & 91 & 93 \\
\hline
\end{tabular}

Source: Authors' calculations, based on microdata from China's Industrial Survey. 
Table 7. Total Factor Productivity Growth and Market Entry, 1998 to $2007^{\text {a }}$

\begin{tabular}{|c|c|c|c|}
\hline & (1) & (2) & (3) \\
\hline \multicolumn{4}{|c|}{ Dependent variable $=$ Total factor productivity growth, state-owned firms ${ }^{b}$} \\
\hline Private entry rate ${ }^{c}$ & $\begin{array}{c}0.737 \\
(0.251)\end{array}$ & & \\
\hline State entry rate ${ }^{\mathrm{d}}$ & & $\begin{array}{c}3.613 \\
(1.019)\end{array}$ & \\
\hline$\Delta$ State Herfindahl ${ }^{\mathrm{e}}$ & & & $\begin{array}{l}-0.160 \\
(0.0711)\end{array}$ \\
\hline$R^{2}$ & 0.213 & 0.282 & 0.137 \\
\hline \multicolumn{4}{|c|}{ Dependent variable $=$ Total factor productivity growth, privatized firms $s^{\mathrm{f}}$} \\
\hline Private entry rate & $\begin{array}{c}0.874 \\
(0.236)\end{array}$ & & \\
\hline State entry rate & & $\begin{array}{c}3.419 \\
(0.947)\end{array}$ & \\
\hline$\Delta$ State Herfindahl & & & $\begin{array}{l}-0.183 \\
(0.0671)\end{array}$ \\
\hline$R^{2}$ & 0.307 & 0.296 & 0.189 \\
\hline \multicolumn{4}{|c|}{ Dependent variable $=$ Total factor productivity growth, private firms ${ }^{\mathrm{g}}$} \\
\hline Private entry rate & $\begin{array}{c}1.284 \\
(0.337)\end{array}$ & & \\
\hline State entry rate & & $\begin{array}{c}1.587 \\
(1.707)\end{array}$ & \\
\hline$\Delta$ State Herfindahl & & & $\begin{array}{c}-0.0266 \\
(0.110)\end{array}$ \\
\hline$R^{2}$ & 0.312 & 0.026 & 0.002 \\
\hline
\end{tabular}

Source: Authors' calculations, based on microdata from China's Industrial Survey.

a. Dependent variables are average annual TFP growth rates of median firms of each type in the balanced panel from 1998 to 2007. Each observation is a two-digit industry (N=34). Standard errors clustered by industry in parentheses.

b. State-owned firms are state-owned in 1998 and 2007.

c. Number of new private firms/total private firms in each year.

d. Number of new state-owned firms/total state-owned firms in each year.

e. $\Delta$ State Herfindahl is the average change in the Herfindahl index for state-owned firms in the balanced panel.

f. Firms that were stated-owned in 1998 and privately owned in 2007.

g. Firms that were privately owned in both 1998 and 2007.

is about 2.1 percent per year, with a standard deviation of 0.8 percentage points across two-digit sectors (the correlation between the private entry rate and state firm entry rate is approximately 0.6). Column 2 in table 7 shows that the entry rate of state-owned firms is also positively correlated with the TFP growth of state-owned firms. Comparing the $R^{2}$ in columns 1 and 2, it appears that the entry of new state-owned firms explains more of the variation in TFP growth among surviving state-owned firms. The entry 
rate of state-owned firms is also positively correlated with TFP growth in the privatized state-owned firms, but not in the surviving private firms.

More generally, an explicit goal of the central government's industrial reorganization plans was to generate competition among the state-owned firms. In the case of the automobile industry, Dunne (2011) argues that the main competition faced by Shanghai-GM (GM's joint venture with the state-owned SAIC Group) is between the two large automobile companies owned by its joint-venture partner SAIC Group. For example, Dunne (2011) describes how SAIC's joint venture with Volkswagen introduced the Volkswagen Passat to undercut Shanghai-GM's profits from the Buick. To capture this force, we measure the market power of state-owned firms using the Herfindahl index. Column 3 in table 7 shows that TFP growth among surviving state-owned firms is lower in sectors in which the Herfindahl index of surviving state-owned firms increases. This fact also suggests that the high TFP growth rate among surviving stateowned firms is not simply mismeasured monopoly power. If it were, then we should find a positive correlation between the market concentration of state-owned firms and the same firms' TFP growth. However, the facts suggest that the exact opposite is true.

Finally, there is some evidence that unsuccessful state-owned conglomerates are forced to sell their firms to other state-owned conglomerates. For example, the Baoshan Steel Company, discussed earlier, is perhaps the most successful steel manufacturer in China. Since 2007, its parent company (the BaoSteel Group) has acquired three large steel manufacturers owned by other state-owned industrial groups. ${ }^{28}$ One of these companies is ShaoSteel, a publicly traded steel manufacturer that was owned by local governments in Guangdong Province. After ShaoSteel suffered losses totaling almost USD 400 million between 2008 and 2012, the BaoSteel Group acquired the firm in 2012. ${ }^{29}$ The case of the Nanjing Automotive Group (owned by the local government of Nanjing) is another example. This company also ran perpetual deficits before the SAIC Group acquired it in 2007.

There are no systematic data on the extent of this reallocation, but some basic facts about the groups and firms owned by the central SASAC suggest this may have been important. When the central SASAC was first

28. Specifically, BaoSteel acquired Bayi Steel in 2007, Ningbo Steel in 2007, and ShaoSteel in 2012.

29. The data on losses from 2008 to 2012 is from ShaoSteel's annual reports. News reports indicate that ShaoSteel's senior management was replaced after the firm was acquired by the BaoSteel Group. 
established in 2003, it was in charge of 189 industrial groups that controlled a total of 15,546 firms. By 2010, the number of industrial groups it owned had been whittled down to 124 . At the same time, these 124 groups controlled a total of 23,738 firms. Put differently, due to this reallocation process, the number of firms controlled by the average central SASAC group increased from about 82 in 2003 to 191 in 2010.

\section{Implications for Aggregate Output}

We now turn to the assessment of the aggregate implications of the changes observed in the state sector. Although it might seem that high TFP growth and a reduction in labor distortions in the state sector would have positive effects on aggregate welfare, there will be offsetting effects in general equilibrium. As discussed in the theoretical model in section II, depending on the parameter values, the effect on allocative efficiency of TFP growth among firms where marginal products are low offsetting effects may be large enough that aggregate output is lower when state-owned firms increase TFP.

We start with the 2007 data and then calculate aggregate output under two counterfactuals, which we will call "Let Go of the Small" and "Grasp the Large," defined this way:

- "Grasp the Large" assumes that (i) TFP and distortions of surviving state-owned firms would be the same as their initial values; and (ii) no new state-owned firms would be established.

- "Let Go of the Small" assumes that (i) TFP and distortions of privatized firms would be the same as their initial values; and (ii) exiting state-owned firms would survive, with TFP and distortions equal to their initial values.

In each counterfactual, we start with the 2007 data and calculate the hypothetical level of aggregate output under each scenario. We keep the aggregate labor supply fixed and assume that the aggregate supply of capital is available elastically at an exogenously determined world interest rate in the benchmark calculation (we relax this assumption later).

Table 8 presents the percentage decline in aggregate output in 2007 in each scenario. The first column, "No surplus labor," assumes that $\tau_{i}^{L}$ represents gaps in the marginal product of labor, so here any increases in TFP among firms with a sufficiently low average product of labor may lower aggregate output. The first three rows present the effect of the closure and privatization of state-owned firms. The first row shows that 2007 aggregate 
Table 8. Productivity Gains from "Grasp the Large, Let Go of the Small," 1998 to $2007^{\text {a }}$

\begin{tabular}{lccccc} 
& \multicolumn{2}{c}{ Open economy } & & \multicolumn{2}{c}{ Closed economy } \\
\cline { 2 - 3 } \cline { 5 - 6 } & $\begin{array}{c}\text { No surplus } \\
\text { labor }\end{array}$ & $\begin{array}{c}\text { Surplus } \\
\text { labor }\end{array}$ & & $\begin{array}{c}\text { No surplus } \\
\text { labor }\end{array}$ & $\begin{array}{c}\text { Surplus } \\
\text { labor }\end{array}$ \\
\hline "Let Go of the Small" & 1.6 & 3.2 & & 0.0 & 0.9 \\
Exit & 0.3 & -0.5 & & 0.4 & 0.0 \\
Privatization & 1.4 & 3.7 & & -0.4 & 0.9 \\
"Grasp the Large" & 10.0 & 18.4 & & -3.5 & 0.9 \\
Surviving state firms & 6.1 & 13.2 & & -4.6 & -0.9 \\
New firms & 5.3 & 7.2 & & 0.5 & 1.6 \\
"Grasp the Large" & 11.4 & 21.0 & & -3.0 & 1.9 \\
"Let Go of the Small" & & & & & \\
\hline
\end{tabular}

Source: Authors' calculations, based on microdata from China's Industrial Survey.

a. This table reports the percentage increase of 2007 aggregate output in each counterfactual relative to that in the benchmark case.

output in the "Let Go of the Small" counterfactual is 1.6 percent lower. The next two rows present the effects of exit versus the effects of privatization.

Exit has a positive effect, increasing aggregate output by 0.3 percent. Privatization alone raises aggregate output by 1.4 percent. Both results deserve comment. The reason the effect of privatization is relatively small despite firms' TFP gains is that output per worker among privatized firms is still lower than the average. Since we assume that lower average product reflects lower marginal product, higher TFP among these firms worsens the allocation of labor, which offsets the effect of higher TFP on aggregate output. ${ }^{30}$ The positive effect of exit on aggregate output is also driven by the same force. In the model we use, exit always lowers aggregate output when resources are allocated efficiently. However, when the marginal product of labor in exiting firms is low, which is the case in China, exit improves the allocation of labor. In the Chinese context, the marginal product of labor is low enough that the effect of improved allocation due to exit more than offsets the direct effect of exit on aggregate output.

The next three rows present the effect of "Grasp the Large," which accounts for 10 percent of 2007 aggregate output. The reforms among surviving state-owned firms raise the 2007 aggregate output by 6.1 percent,

30. Our benchmark parameterization implies a mean of 0.78 for $\chi$ across industries (see equation 14). We have shown that the labor productivity of state-owned and privatized firms was about half and three-quarters that of private firms in 1998 and 2007, respectively. Therefore, many state-owned and privatized firms would easily satisfy the condition. 
and the creation of new state-owned firms accounts for 5.3 percent of the aggregate output in 2007. The fact that newly formed state-owned firms contribute almost as much to aggregate output as surviving state-owned firms may be surprising, given that total value added of surviving stateowned firms in 2007 was about four times larger than that of the new state-owned firms. The difference in the contribution of these groups of large state-owned firms stems from the fact that average labor productivity among new state-owned firms is about the same as that of the average private firm, so the entry of these firms does not worsen the allocation of labor. In contrast, the average product of labor among state-owned firms in 2007 was still lower than that of the average private firm. Consequently, as in the case with privatized state-owned firms, here higher TFP among state-owned firms worsens the allocation of labor, which offsets the effect of higher firm TFP on aggregate output.

The estimates in column 1 assume that gaps in the average product of labor reflect differences in the marginal product. However, the evidence presented in section III suggests that the convergence of labor productivity between state-owned and private firms can be explained by the reduction in the number of surplus workers in the state sector (instead of an increase in the marginal product of labor in state-owned firms). In column 2, we assume that (i) gaps in the average product of labor between stateowned and private firms entirely reflect the number of redundant workers in the state sector but that the marginal product of labor is the same in the two sectors; ${ }^{31}$ and (ii) redundant workers in the state sector have zero productivity and, hence, reducing $f_{i}$ does not affect labor supply. With those assumptions, TFP growth in firms with low labor productivity does not worsen the allocation of labor. As can be seen, the effects on aggregate output are now almost twice as large (compared to the estimates in column 1). "Let Go of the Small" accounts for 3.2 percent of aggregate output in 2007, and "Grasp the Large" accounts for 18.4 percent. The two reforms together, shown in the last row, account for 21.0 percent of aggregate output in 2007.

We have so far assumed that the aggregate supply of capital in China is perfectly elastic. This can be the case because of capital mobility or because a consumption Euler equation generates a constant interest rate. Zheng Song, Kjetil Storesletten, and Fabrizio Zilibotti (2011) document that savings have exceeded investments in China, suggesting that an open economy with an elastic supply of capital is a reasonable assumption for the country.

31. $f_{i} / \mathrm{L}_{\mathrm{i}}$ is assumed to be the same among state-owned firms. 
In addition, Chong-En Bai, Chang-Tai Hsieh, and Yingyi Qian (2006) find that the return to capital among nonstate firms was roughly constant over this time period, which is consistent with a fixed cost of capital.

Nonetheless, it is useful to examine the welfare effects when we assume a fixed capital stock at the aggregate level. The results are reported in the last two columns. Since the marginal product of capital is lower among surviving state-owned firms, privatized state-owned firms, and newly established state-owned firms, the implication of a fixed capital stock is that higher productivity growth among these firms raises the equilibrium interest rate and worsens the allocation of capital. Column 3 further assumes that low labor productivity reflects low marginal product, so the effect of TFP growth among low-labor-productivity firms also worsens the allocation of labor. This is the worst-case scenario, because higher TFP growth among state-owned firms potentially worsens the allocation of both labor and capital. As can be seen, the effect of this alternative assumption is dramatic. For example, the effect of higher TFP growth among surviving stateowned firms worsens aggregate output by almost 5 percent. Intuitively, the marginal products of capital and labor were low enough in these firms in 2007 that the effect of higher TFP on resource misallocation should overwhelm the direct effect of higher TFP on aggregate output. This effect is less strong among the newly established state-owned firms. This is because the creation of these firms worsens the allocation of capital (the average productivity of capital is lower in these firms) but not the allocation of labor (their average productivity of labor is about the same as the average).

The last column assumes that gaps in labor productivity reflect redundant workers (as in column 2). Here, higher TFP growth in low-laborproductivity firms has no effect on the efficiency of labor allocation. Thus, comparing columns 2 and 4 isolates the effect of TFP on capital allocation. The effect of worse capital allocation due to TFP growth in low-capitalreturn firms is very large. The effect of worse capital allocation due to TFP growth among surviving state-owned firms lowers aggregate output by more than 14 percent $(13.2+0.9)$. The effect of worse capital allocation due to the entry of state-owned firms that have high TFP but low capital return lowers aggregate output by 5.6 percent $(7.2-1.6)$.

In summary, the magnitude of the welfare gain depends on how elastic the capital supply is. If the reality is that the cost of capital to private firms does not change due to the reform of state-owned firms, the effect of the reform is likely to have increased aggregate output significantly. Similarly, the effect of TFP growth also depends on the extent to which it worsens the allocation of labor. Although we present evidence that the convergence 
between state and private firms in labor productivity is due to the reduction in redundant workers, we do not know whether the remaining gap in 2007 reflects differences in the marginal product of labor or in the number of redundant workers.

Finally, following the same steps as described above, we find that the exit and closure of state-owned firms from 2007 to 2012 had a negligible effect on aggregate output growth over this time period. In turn, the transformation among incumbent state-owned firms and the creation of new state-owned firms over this time period (their "corporatization") account for approximately 18 percent of aggregate growth from 2007 to 2012. ${ }^{32}$ Thus, the transformation of the state sector continues to play an important role in China's growth, but its importance relative to other forces has remained small since 2007.

\section{Conclusion}

We document the dramatic transformation of Chinese state-owned firms after the late 1990s. Smaller state-owned firms were closed or privatized; large state-owned firms were corporatized and merged into large stateowned holding companies; and new state-owned firms were created. We show that labor productivity and TFP increased in the privatized and surviving state-owned firms. In contrast, there was little convergence in the capital productivity of state-owned and privatized firms after 1998. Among the newly established state-owned firms, we show that TFP and labor productivity of state-owned firms are about the same as those of their private counterparts, while capital productivity of state-owned firms is significantly lower.

Although these changes unambiguously increase state-sector profits, the effects on welfare are more ambiguous. If higher TFP in state-owned firms does not worsen resource allocation, then the reform of the state sector was potentially responsible for 20 percent of aggregate output in 2007. However, if the aggregate supply of capital is fixed, the effect of higher TFP and the creation of new high-TFP state-owned firms could have worsened the allocation of capital by enough that the net effect on aggregate output may be negative. Likewise, if the marginal product of labor among state-owned firms is low, higher TFP can also lower aggregate output by reallocating workers away from private firms, where the marginal product of labor is presumably higher.

32. We conduct counterfactuals for 2007-12 in an open economy with no surplus labor. 
We end with three suggestions for future work. First, although we provide suggestive evidence that changes in corporate governance, competition from private firms and other state-owned groups, and reallocation of assets between state-owned groups may have been important drivers of the changes observed in state-owned firms, the evidence is far from conclusive. Second, our analysis of the welfare effect of "Grasp the Large, Let Go of the Small" relies on a specific model, but the effect may be different with a different model. Finally, although our estimates suggest that the transformation of the state sector, particularly the corporatization of state-owned firms and the creation of new state-owned firms, was an important force behind China's growth, it is clear that the main driver of China's growth is something else. Figuring out the unexplained residual in this paper is clearly a central question for future work.

ACKNOWLED G M ENTS We thank Wancong Li and Jie Luo for excellent research assistance and Loren Brandt, Amit Khandelwahl, and the editors for helpful comments. 


\section{References}

Aivazian, Varouj A., Ying Ge, and Jiaping Qiu. 2005. "Can Corporatization Improve the Performance of State-Owned Enterprises Even without Privatization?" Journal of Corporate Finance 11: 791-808.

Bai, Chong-En, Chang-Tai Hsieh, and Yingyi Qian. 2006. "The Returns to Capital in China." Brookings Papers on Economic Activity, Fall: 61-102.

Baily, Martin, Charles Hulten, and David Campbell. 1992. "Productivity Dynamics in Manufacturing Plants." Brookings Papers on Economic Activity, Microeconomics 187-267.

Brandt, Loren, Johannes Van Biesebroeck, and Yifan Zhang. 2012. "Creative Accounting or Creative Destruction? Firm-Level Productivity Growth in Chinese Manufacturing." Journal of Development Economics 97: 339-51.

Central Committee of the Communist Party of China. 1999. "The Decision of the Central Committee of the Communist Party of China on Major Issues Concerning the Reform and Development of State-Owned Enterprises." Adopted at the Fourth Plenum of the 15th Communist Party of China Central Committee on September 22, 1999. http://www.lawinfochina.com/display. aspx?lib=law\&id=991\&CGid

Dai, Yuanchen. 1996. Employment and Income in an Economy with Surplus Labor (in Chinese). Shanghai: Far East Publishing House.

Dunne, Michael. 2011. American Wheels, Chinese Roads: The Story of General Motors in China. Hoboken: Wiley.

Kamal, Fariha, and Mary E. Lovely. 2013. "Labor Allocation in China: Implicit Taxation of the Heterogeneous Non-State Sector." CESifo Economic Studies 59: 731-58.

Lardy, Nicholas R. 2014. Markets over Mao: The Rise of Private Business in China. Washington: Peterson Institute for International Economics.

Perkins, Dwight H., and Thomas G. Rawski. 2008. Appendix to "Forecasting China's Economic Growth to 2025." In China's Great Economic Transformation, edited by Dwight H. Perkins and Thomas G. Rawski. Cambridge University Press.

Song, Zheng, Kjetil Storesletten, and Fabrizio Zilibotti. 2011. "Growing Like China." American Economic Review 101: 202-41.

Song, Zheng, and Guiying Laura Wu. 2014. "Identifying Capital Misallocation." Working Paper. http://faculty.chicagobooth.edu/zheng.song/research/SW_ web.pdf. 


\section{Comments and Discussion}

\section{COMMENT BY}

LOREN BRANDT In "Grasp the Large, Let Go of the Small," ChangTai Hsieh and Zheng Song tackle the central issue of the reform of stateowned enterprises (SOEs) in China in the late 1990s, an issue that once again is very high on the policy agenda. Two major findings emerge from their analysis: First, the benefits to aggregate growth of the privatization and bankruptcy of tens of thousands of smaller SOEs in industry were negligible; second, the productivity gains for those SOEs that remained and the establishment of new SOEs were the source of a fifth or more of total growth between 1998 and 2012. The latter finding would suggest that an important contribution to growth comes from reforms aimed at paring back the role of the state to limit it to those sectors deemed key or strategic.

I would like to focus on several issues. First, there is a need to put the SOE reform into the slightly larger context of overall economic reform during this period. Second, the paper's findings could be sensitive to measurement issues, the most important of which relates to assumptions about the production technologies of SOEs versus non-SOEs. Third and finally, I would like to highlight the value of extending the analysis beyond industry to include the service sector.

HISTORICAL CONTEXT It is useful to begin by putting this set of reforms in context. Up through the mid-1990s, policymakers in China eschewed more radical measures for the state sector such as worker layoffs, bankruptcy, and privatization. The lack of a social safety net and limited outside labor market opportunities made such policies highly risky. Ideology and powerful vested interests likely factored in as well. Thus, early reforms of the SOEs largely tinkered with expanding firm and managerial discretion, better aligning control and residual income rights, hardening firm budget constraints, and opening up a growing number of sectors to competition. 
The general consensus, however, is that the gap in productivity between state and nonstate firms widened, with nonperforming loans in the statedominated banking sector accumulating to more than half of state-owned banks' loan portfolios.

When a reform of the state sector began in earnest in the mid- to late1990s - massive layoffs in fact began in 1995-they did not occur in isolation. Other major policy initiatives included domestic market liberalization tied to China's entry into the World Trade Organization, a lowering of barriers for private sector firms' entry into industry, a relaxation of geographic restrictions on individual mobility, and, finally, a recapitalization and restructuring of the major state-owned banks. The last initiative would be pivotal in enabling these banks to advance state interests through new lending. In 2003, the State Asset Supervisory Administrative Commission (SASAC) was also established with the express purpose of enabling the state to better manage the assets of the SOEs (Naughton 2015). The simultaneity of these reforms also makes it difficult to attach a causal interpretation to any single reform.

MEASUREMENT ISSUES Two measurement issues deserve special attention: the difficulty of identifying if enterprises are state-owned and controlled, and too-rigid assumptions about the level of technology to which all firms have access.

Ownership. As Hsieh and Song point out, simply identifying an SOE poses its own set of difficulties. The authors utilize information on the share of registered capital held directly by the state and the identity of the controlling shareholder to identify ownership. For the largest of SOEs, this method likely works well. However, as a member of an enterprise group or jituán, a typical SOE is part of a huge hierarchy made up of multiple layers of firms that are linked through complicated ownership and input-output relationships. For example, each of the 109 centrally administered SOEs currently has a hundred or more subsidiaries under its control and may have up to an additional half or three-quarters that number in which it has invested but does not have control. As one moves down the hierarchy, accurately identifying ownership and control becomes more difficult. Interestingly, data reported by SASAC reveal that between 2003 and 2012 there was very little reduction in the number of SOEs under state control but a significant increase in the value of state assets under state control. More work is needed to identify these relationships and to estimate their effects on firm behavior and outcomes.

Production Technology and Productivity. As is common in the macrooriented literature on misallocation, the authors assume that the underlying 
production technology in each sector follows Cobb-Douglas with constant returns to scale. They allow for differences in the Cobb-Douglas technology across sectors but assume that all firms within a sector-state and nonstate-have access to the same production technology and identical factor shares. These assumptions seem highly restrictive. Moreover, this "rigidity" in assumptions about the deterministic portion of a firm's production function likely spills over into estimates of total factor productivity in ways that may be systematically related to variables such as ownership and intensity of factor use.

There are alternatives, however. One of them is to allow for a more flexible functional form in the technology, such as constant elasticity of substitution or translog. Either functional form allows the elasticity of substitution to differ from 1 and for the output elasticity with respect to $K, L$, and $M$ within a sector to differ among firms and to depend in a nonlinear way on input levels and the underlying production parameters. Working with the same data as Hsieh and Song, but using parameter estimates from the estimation of a translog at the two-digit level (using the method spelled out by De Loecker and Warzynski [2012]) paints a different productivity picture (Brandt and others 2012 [revised 2015]; also see Berkowitz and others 2015).

Productivity growth of SOEs at both the firm- and sector-ownership level is consistently lower than that observed in nonstate firms. Moreover, at the two-digit level, there is a stark negative relationship between the role of the state in the sector in 1998 and productivity gains in the sector between 1998 and 2007 (see my figure 1, left panel). The sectors in which the state dominates are typically those identified as strategic or pillar, with state sector shares in 1998 highly correlated with those in 2007. The raw correlation is 0.96 . Decompositions of the change in productivity between 1998 and 2007 in these sectors point to two culprits: the poor productivity performance of incumbents in the sector and (quantitatively even more important) new entrants whose levels of productivity are actually lower than those of the incumbents. This behavior is true for both state and nonstate actors in these sectors, suggesting important "negative" spillovers from the state to the nonstate in sectors where the state dominates. It is the exact opposite of the behavior we observe in more dynamic sectors and in industry overall (Brandt, Van Biesebroeck, and Zhang 2012). The results are also at odds with those reported in Hsieh and Song's paper.

Paradoxically, my figure 1 (right panel) shows that between 1998 and 2007, the sectors dominated by state-owned firms are the sectors that experienced the most rapid growth in profitability. A possible explanation for 
Figure 1. Impact of State-Owned Enterprises (SOEs) on Sector Productivity and Profitability

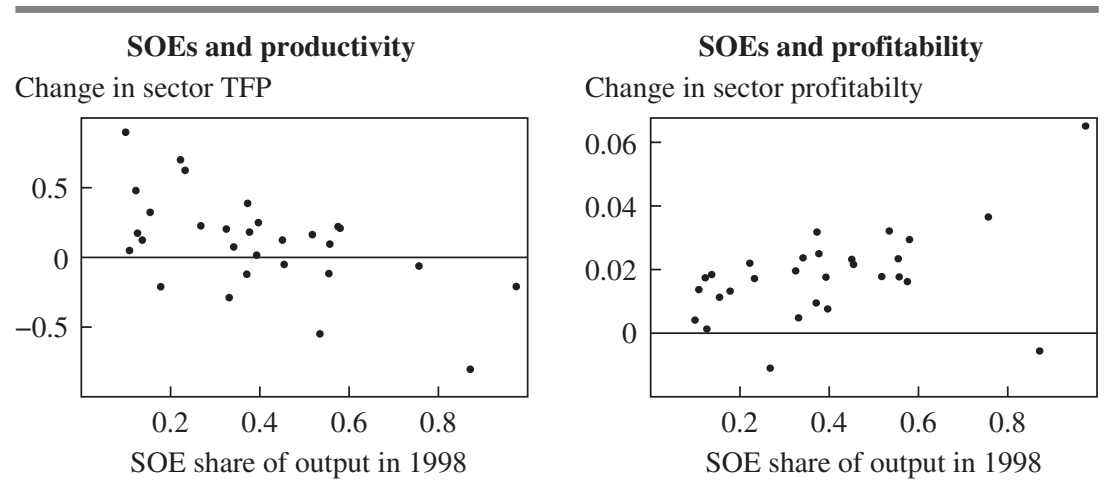

Source: Author's calculations based on the same NBS firm-level data used by Hsieh and Song and method spelled out by De Loecker and Warzynski (2012).

this behavior is that rents in these sectors, tied to less expensive access to inputs such as capital and land, eliminated firm pressures to reform and simultaneously distorted the entry process.

In painting this more negative picture of state sector firms, some care needs to be taken. There are both sectors in which state-owned firms are important and state-owned firms in sectors where the state is much less important that have performed reasonably well. My table 1 highlights six two-digit sectors where state-owned firms were dominant in 1998 but with highly mixed outcomes. At a minimum, sector-level policies are as important as ownership in determining outcomes, and there is more to learn here.

THE NEGLECTED SERVICE SECTORS Hsieh and Song focus on ownership reform in industry, but even more important now in terms of gross domestic product, employment, and the role of SOEs in the economy is China's service sector. Services such as information technology, banking and finance, and logistics are also increasingly important inputs into industry. ${ }^{1}$ The success of firms such as Alibaba, and Tencent (developer of China's extremely popular smartphone app WeChat) are well documented in the western media, but the tertiary sector is highly segmented, with strategic and more capital-intensive sectors such as telecom, banking and finance, and transportation being state-dominated due to relatively high barriers to private

1. From the perspective of the 2007 Chinese input-output table, inputs from services constitute more than 40 percent of inputs into industry. 


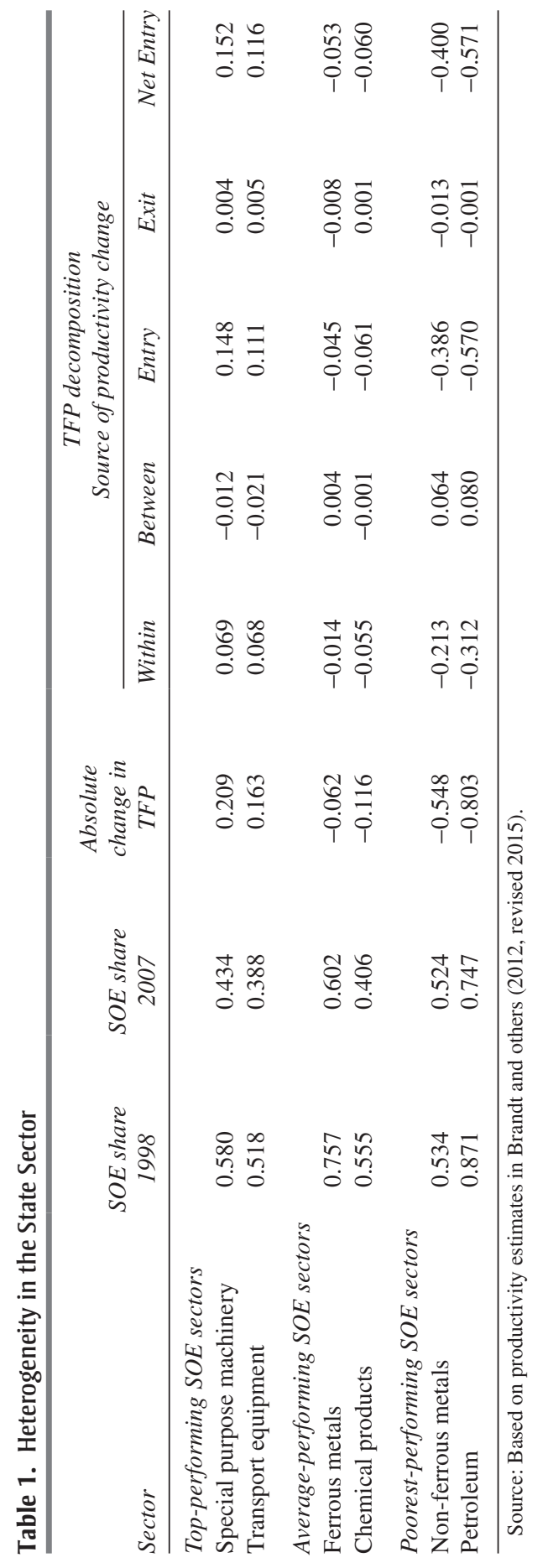


and foreign firm entry. In contrast, the more labor-intensive sectors, such as retail and hospitality, are largely private. Firm-level data of the type commonly used for industry are not available for the services sector, but aggregate assessments suggest that productivity and returns to capital in services are considerably lower in services than they are in industry (Brandt and Zhu 2010). Emblematic of these difficulties are the relatively low reported rates of capacity utilization in telecom networks and the power sector, as well as the comparatively high prices paid for these services. ${ }^{2}$

Currently, there is much discussion in policy circles in China about opening these sectors and the SOEs in them to nonstate ownership and investment. Most observers are not overly optimistic about the prospects. First, most private entrepreneurs do not want to invest in larger SOEs without obtaining control, and this seems unlikely. Second, as long as the National Development and Reform Commission (NDRC) regulates entry into some of these sectors, the process will remain highly politicized, and outcomes highly uncertain. And finally, growing national security concerns make an expanded role for foreign firms highly unlikely. In industry, in combination with sharply falling tariff and nontariff barriers, foreign firm entry was an important source of competition and knowledge spillovers that helped to propel the sector forward.

LARGER LESSONS Perhaps the most important effect of the reform efforts in the mid-1990s was that by getting rid of the smaller SOEs and cleaning up the balance sheets of the banks, the state freed up resources for infusion into larger and often new SOEs in sectors that were deemed important. My figure 2, which graphs real capital formation in the state and nonstate sectors as a proportion of gross domestic product over this period, lines up with other information on the growth of assets under state control. ${ }^{3}$ The continued expansion of the state sector has generated all kinds of rents in the process, and as the correlations between state ownership and productivity growth suggest, it probably did not do much to foster dynamism in these sectors. China's ability to grow at 6 to 7 percent a year in the future will depend critically on what the state decides to do with these sectors.

2. Interviews I carried out with one of the three leading telecom providers in the fall of 2013 revealed utilization rates for their $3 \mathrm{G}$ network of only 35 percent, which they reported was higher than their two competitors' rates. In the power sector, capacity utilization rates for hydro and more efficient thermal power plants are only 50 percent.

3. Between 2003 and 2011, SASAC reported that assets in the state sector increased from 19.7 trillion to 85.4. trillion RMB, implying an annual increase of roughly 20.1 percent. 
Figure 2. Capital Formation as a Proportion of GDP, 1978-2011

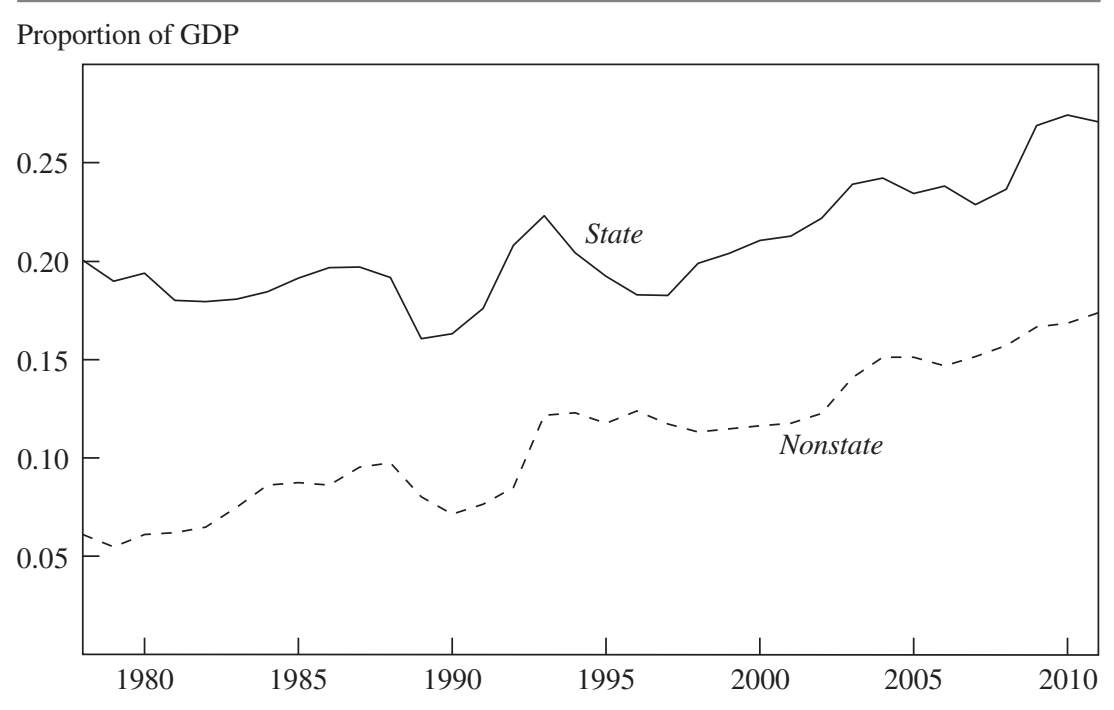

Source: Author's updated estimates, based on those found in Brandt and Zhu 2010.

\section{REFERENCES FOR THE BRANDT COMMENT}

Berkowitz, Daniel, Hong Ma, and Shuichiro Nishioka. 2015. "Recasting the Iron Rice Bowl: The Reform of China's State Owned Enterprises." In Proceedings of the 2015 Annual Meeting of the International Society of New Institutional Economics. http://extranet.isnie.org/uploads/isnie2015/berkowitz_ma_nishioka.pdf

Brandt, Loren, Johannes Van Biesebroeck, and Yifan Zhang. 2012. "Creative Accounting or Creative Destruction? Firm-Level Productivity Growth in Chinese Manufacturing." Journal of Development Economics 97, no. 2: 339-51.

Brandt, Loren, Johannes Van Biesebroeck, Luhang Wang, and Yifan Zhang. 2012. "WTO Accession and Performance of Chinese Manufacturing Firms." Working Paper no. 9166. Washington: Center for Economic Policy Research.

Brandt, Loren, and Xiaodong Zhu. 2010. "Accounting for China's Growth.” Discussion Paper no. 4764. Bonn, Germany: Institute for the Study of Labor (IZA).

De Loecker, Jan, and Frederic Warzynski. 2012. "Markups and Firm-Level Export Status." American Economic Review 102, no. 6: 2437-71.

Naughton, Barry. 2015. "The Transformation of the State Sector: SASAC, the Market Economy, and the New National Champions." In State Capitalism, Institutional Adaptation, and the Chinese Miracle, edited by Barry Naughton and Kellee S. Tsai. Cambridge University Press. 


\section{COMMENT BY}

AMIT KHANDELWAL While western economies have been struggling since the Great Recession, economic growth in emerging markets has been strong, particularly in those, like China, where the state plays a seemingly active role. In 2012, The Economist ran a special report charting the rise of powerful state-backed companies in emerging markets. As the report's author, Adrian Wooldridge, put it: "The era of free-market triumphalism has come to a juddering halt." 1

My table 1, reproduced from Przemyslaw Kowalski and others (2013), provides a sense of the importance of state-owned enterprises (SOEs) in some large developing countries. At the top are Chinese SOEs with sales that are 26 percent of gross national income, but the relative importance of state firms in Brazil, India, and Russia is also high. While scale can be important for businesses, the inefficiencies of SOEs are also well known. Reform-minded policymakers are looking at the evolution of China's state sector for lessons learned.

The broad strokes of China's state-sector reforms are well documented. During the mid-1990s, China faced a fiscal crisis stemming in part from widespread nonperforming loans issued to SOEs. According to Nicholas Lardy (2014), in 1998, 40.6 percent of China's SOEs were losing money, and these losses totaled 1.4 percent of gross domestic product. Evergreening of loans had become commonplace, and efficiency was abysmal. In response to these serious performance problems, the government sought to reform the state sector using a policy that would follow the maxim "Grasp the Large, Let Go of the Small." Small SOEs would be shuttered or privatized, and large SOEs would be merged into conglomerates and restructured. What restructuring would entail was not exactly clear, but it was thought to have meant a refocusing by SOEs to maximize profits instead of pursuing other objectives. At the time, SOEs still dominated manufacturing sectors in China, accounting for approximately 52 percent of employment, 42 percent of value added, and 60 percent of the real capital stock in China's industrial sector. ${ }^{2}$ Given the scale of these firms, the reform appeared capable of having an impact on global output.

The success of the reform has been hard to pin down. Daniel Berkowitz, Hong Ma, and Shuichiro Nishioka (2014) find that the profitability of SOEs

1. Adrian Wooldridge, "The Visible Hand." Economist, January 21, 2012. http://www. economist.com/node/21542931

2. See table 1 in Berkowitz, Ma, and Nishioka (2014). 
Table 1. SOE Sales, Profits, Assets, and Market Values as a Percentage of Gross National Income

\begin{tabular}{|c|c|c|c|c|c|}
\hline & Sales & Profits & Assets & $\begin{array}{c}\text { Market } \\
\text { value }\end{array}$ & $\begin{array}{l}\text { Share in } \\
\text { top } 10 \text { firms }\end{array}$ \\
\hline Brazil & 12 & 2 & 51 & 18 & 50 \\
\hline China & 26 & 3 & 145 & 44 & 96 \\
\hline India & 16 & 4 & 75 & 22 & 59 \\
\hline Indonesia & 3 & 0 & 19 & 12 & 69 \\
\hline Russia & 16 & 3 & 64 & 28 & 81 \\
\hline South Africa & 2 & 2 & 3 & 1 & 2 \\
\hline
\end{tabular}

Source: Kowalski and others (2013).

a. Reports an equally weighted average of SOE shares of sales, assets, and market values among the country's top 10 firms.

did, in fact, improve markedly during the 2000s. Productivity also appears to have improved, though not nearly at the rate of the private sector. ${ }^{3}$ This is consistent with anecdotal evidence. I recently led a group of MBA students to China and witnessed the legendary inefficiency first-hand at a large SOE when the company sent several dozen employees to attend a two-hour meeting, despite having no apparent way to contribute to the conversation (few spoke or understood English). Richard McGregor's 2012 book The Party: The Secret World of China's Communist Rulers is full of stories about SOEs' inefficiency and their lack of independence. Quoting one banker, he writes: "At all the major state companies, the party meetings are held regularly before board meetings" (page 85). Joseph Fan, Randall Morck, and Bernard Yeung (2011), among others, have echoed the view that SOE boards remain beholden to the Communist Party. Some argue that the benefits of these political connections may outweigh the inefficiency costs in a country like China. For example, Charles Calomiris, Raymond Fisman, and Yongxiang Wang (2010) find that stock prices of listed SOEs fell when the Chinese government announced the sale of government-owned shares among listed companies; normally, one would expect investors to reward such news.

While these studies analyze particular aspects of the policy—profitability, productivity, and corporate governance-what is missing from the literature is a quantitative assessment of state-sector reforms on China's aggregate 
output. After tallying up the direct effects, and after accounting for general equilibrium implications, just how effective were the SOE reforms for China's economy?

Chang-Tai Hsieh and Zheng Song fill this large gap. Their paper is a timely analysis that contributes to the intense debate concerning the future of China's economic growth. Their findings document dramatic changes within the state sector between 1998 and 2012, including these: (i) the share of revenue by SOEs fell from roughly 40 percent to 12 percent; (ii) the fraction of SOEs that were registered as private firms increased from roughly 15 percent to 60 percent; and (iii) there has been significant churn within the state sector: roughly 83 percent of SOEs operating in 1998 were either closed or privatized, and approximately one-third of firms operating in 2007 were newly established.

The authors filter these facts through the lens of a standard heterogeneous firm model to quantify the implications of SOE reforms on aggregate output. Two key facts emerge: total factor productivity (TFP) among SOEs improved, and revenue per worker-which in their model is equivalent to the marginal product of labor-converged to that of their privatesector counterparts. Yet despite improvements in performance, the authors' counterfactual analysis reveals that the reform had only limited effects on output. Essentially, this finding reflects the fact that marginal products among SOEs remain low relative to incumbent private firms. Reallocation toward these firms blunts the positive effects on aggregate output coming from any productivity gains.

Their model is transparent, and I have little to quibble with about their setup. One could imagine tweaking some of their assumptions in the model. For example, allowing for firm-specific markup variation or heterogeneous production technologies might increase the productivity gap between state and nonstate firms. Also, the decline in labor shares might possibly reflect not only the shedding of redundant workers but also preferential access to capital and an elasticity of substitution that exceeds one for these firms. ${ }^{4}$ On the other hand, the impact of SOE reforms might be larger in a multisector model in light of recent evidence from Heiwei Tang, Fei Wang, and

4. Berkowitz, Ma, and Nishioka (2014) argue that the elasticity of substitution between labor and capital exceeds one for these firms, and that SOEs cost of capital relative to labor fell after the "Grasp the Large, Let Go of Small" policy was implemented. If they are correct, I suspect that attributing part of the decline in labor shares to these two forces would lower the impact of the reform in their model. 
Zhi Wang (2014) that SOEs dominate upstream markets. But I suspect that relaxing these assumptions is unlikely to change the headline result. Even in the best-case scenario, the "Grasp the Large, Let Go of the Small" policy explains only one-fifth of China's aggregate industrial output growth. This seems small.

My main comments focus on this breakdown of the contribution of state-sector reforms. In interpreting the authors' results, it is important to realize that in addition to the privatization program that directly addressed SOEs, the government simultaneously pursued additional reforms targeting the state sector. Rather than directly restructuring poorly performing firms, these additional policies sought to reduce the importance of the state sector by dismantling entry barriers. To the extent that these policies also improved the productivity and marginal products of SOEs, Hsieh and Song's counterfactual would capture the combined effects of all reforms that addressed the state sector. But a key outcome of these policies was the direct formation of new firms in the private sector, which is instead captured by the residual component in their model. This makes it difficult to cleanly separate the effects of China's policy reforms on the state and nonstate sectors. As such, I suspect the authors' framework provides a lower bound on the importance of state-sector reforms for China's growth.

"RAPID WATERS SHOULD WASH AWAY DIRTY SANDS" Perhaps the largest of these reforms that occurred simultaneously with the privatization program was China's trade liberalization and entry into the World Trade Organization (WTO) in 2001. China's accession document contains many clauses directed at "leveling the playing field" for domestic and foreign private firms by reducing the monopoly power of SOEs. In fact, China was a vast outlier in the number of commitments it made in order to join the WTO, even relative to other developing countries. ${ }^{6}$ Upon entry, the many barriers to entry that had long protected its SOEs began to dissolve. For example, China agreed to dismantle its web of designated trading licenses that would allow private firms, irrespective of their size, to directly export and import in global markets.

The effects were pronounced. Customs data reveal that private-sector entrants were the major force in driving China's export surge during the

5. A statement attributed to Chinese Premier Zhu Rongji in the 1999 government work report.

6. Tang and Wei (2009) note that China agreed to 147 WTO commitments, as compared with the median of 27 . 
Table 2. State-Owned and Private Exporters and Export Values, 2005

\begin{tabular}{lccr} 
& \multicolumn{3}{c}{ Exporters (number) } \\
\cline { 2 - 4 } & Incumbents $^{\mathrm{b}}$ & Entrants $^{\mathrm{c}}$ & Total \\
\hline State-owned firms & 7,157 & 9,792 & 16,949 \\
Private firms & 24,232 & 102,846 & 127,078 \\
Total & 31,389 & 112,638 & 144,027 \\
& & Exports $^{\left(\$ \text { billions }^{\mathrm{d}}\right.}$ \\
\cline { 2 - 4 } & Incumbents $^{\mathrm{b}}$ & Entrants $^{\mathrm{c}}$ & \\
\hline State-owned firms & 142.7 & 64.6 & Total \\
Private firms & 248.6 & 320.8 & 207.3 \\
Total & 391.3 & 385.4 & 569.5 \\
\hline
\end{tabular}

Source: Author's calculations, based on China customs data.

a. Table decomposes China's customs-level exports in 2005 into two margins by ownership type.

b. Incumbent firms are those that exported in 2000 and 2005.

c. Entrants are firms that exported in 2005 but not in 2000.

d. Reports total exports by cell. State-owned firms include collectives. Private firms include domestic and foreign private firms.

2000s. My table 2 decomposes China's exports in 2005 by ownership and firm margin. The upper panel shows that there were 144,027 exporters that year. About 12 percent-16,949 exporters-were formally registered as state-owned companies. Of the remaining private-sector exporters, the vast majority - 102,846 out of 127,078 — were firms that did not export a product in $2000 .^{7}$ The lower panel decomposes export values. Of the $\$ 776.7$ billion in total exports, private entrants accounted for 41 percent (with private incumbents accounting for another 32 percent). Just five years earlier, the overall private sector only accounted for about half of total exports. This entry would be captured in the residual component of Hsieh and Song's framework, but I would attribute this channel to removing barriers that

7. Due to data limitations, the decomposition relies on official registration. Hsieh and Song make an important point that registration can often mask ultimate ownership in China. Nevertheless, the vast majority of private firms in these customs data are likely to be privately owned, as opposed to state owned. Table 1 in Hsieh and Song's paper indicates that there were roughly 12,000 manufacturing SOEs in 2007, which is much smaller than private firm numbers from customs data. Moreover, using the procedure in Ahn, Khandelwal, and Wei (2011) that removes nonmanufacturing intermediaries does not change the message of the table: of the 121,928 manufacturing exporters in 2005, 110,827 were private firms and of that number 87,247 were entrants. 
protected SOEs. Moreover, the de-licensing episode is likely to have had a direct effect on private-sector productivity given evidence for the link between exporting and productivity gains in developing countries (such as De Loecker 2007 and Atkin, Khandelwal, and Osman 2015).

China's external commitments also help one to understand the political economy behind reducing the role of the state. Daron Acemoglu, Philippe Aghion, and Fabrizio Zilibotti (2006) show that vested interests can lead to development traps because they make it difficult to shut down inefficient but politically connected firms. The WTO tied the hands of reform-minded policymakers and helped them overcome domestic opposition. ${ }^{8}$ Premier Zhu Rongji, who spearheaded China's WTO entry, explicitly appealed to this logic in the quote noted above. Frustrated by bureaucratic opposition to SOE reforms, he viewed WTO accession as an important step toward reducing the role of SOEs. ${ }^{9}$ This argument suggests that China's entry into the WTO was as much about internal reforms as it was about "standard" external reforms, such as lower tariff barriers. Trade liberalization delivered not only the standard gains from trade predicted by textbook models but also helped correct misallocation within the economy.

The evolution of China's apparel industry illustrates this two-pronged effect of China's trade reforms. Starting in the 1950s, developed countries imposed stringent quotas on apparel produced in developing countries; the regime was known as the Multifiber Arrangement (MFA). Developing countries had to allocate export licenses to their domestic apparel firms. In contrast to Hong Kong's use of a transparent auction, China's caseallocation mechanism for distributing licenses was murky. For instance, there are anecdotes that firms controlled by the People's Liberation Army received quota licenses to bolster support following the 1999 Tiananmen Square incident.

Peter K. Schott, Shang-Jin Wei, and I (2013) quantify massive misallocation caused by the licensing regime. Following the removal of quotas for WTO members on January 1, 2005, China's exports immediately surged 119 percent compared to the 29 percent growth in other apparel products not bound by quotas. To identify the size of misallocation, our identification strategy compares export growth, by ownership and margin,

8. See Tang and Wei (2009) for a formal analysis of this argument.

9. See Fewsmith (2001) for a discussion of the politics surrounding China's WTO entry. 
in quota-bound and quota-unbound products immediately before and after the quotas were removed. ${ }^{10}$ It is clear that the licensing institution protected SOEs. Their market shares averaged 62 percentage points in quota-bound products compared to 53 percentage points in unbound products. Immediately after the quotas were removed, SOE market shares in the two groups of products equalized. The data reveal substantial entry of private firms that had been blocked from exporting because they had lacked the connections to obtain quota licenses prior to 2005. Moreover, these entrants had high productivity, as indicated by their low qualityadjusted prices. Numerical simulations reveal that industry productivity would have been 15 percentage points higher without explicit protection to SOEs. (And this counterfactual ignores any direct effects on the productivity of state and private firms.) By simply eliminating the root source of misallocation, namely the quota licenses, the trade liberalization generated large improvements in output and productivity.

These complementary reforms - trade barriers, exchange-rate management, promotion of technology adoption, and so forth-make it tricky to identify the impacts of China's privatization scheme on the state sector in isolation. While the "Grasp the Large, Let Go of the Small" reform surely mattered, so did these other reforms that broke state monopolies and lowered entry barriers for private enterprise. My view is that Hsieh and Song's analysis reflects a lower bound on the role of state-sector reforms for China's growth. It also leaves an important message for other countries seeking to reform their own state sectors: privatization policies matter, but so do complementary market-oriented policies that allow private firms to thrive.

Finally, although the role of the state-owned enterprises in China's economy has changed dramatically since 1978, this is not to say that the role of the state is no longer relevant. Connections to the government remain vital for domestic and foreign private firms. Business people in China will tell you repeatedly that guanxi matters tremendously for the success of any project. ${ }^{11}$ What is the relationship between private enterprises and bureaucrats? How

10. For example, men's cotton pajamas were subject to quotas in the U.S. and Canada but not in the European Union. Comparing export growth by ownership and margin across destinations with narrowly defined products controls for any concurrent changes in supply and demand factors that may have occurred.

11. For example, a recent paper by Fisman and Wang (2015) carefully documents the value of political connections for firms wanting to circumvent regulation (to detrimental effects). 
has it evolved over time? Will it impede or facilitate China's economic transition? Hopefully, future research will tackle these difficult but important questions.

\section{REFERENCES FOR THE KHANDELWAL COMMENT}

Acemoglu, Daron, Philippe Aghion, and Fabrizio Zilibotti. 2006. "Distance to Frontier, Selection, and Economic Growth.” Journal of the European Economic Association 4, no. 1: 37-74.

Ahn, JaeBin, Amit K. Khandelwal, and Shang-Jin Wei. 2011. "The Role of Intermediaries in Facilitating Trade." Journal of International Economics 84, no. 1: 73-85.

Atkin, David, Amit K. Khandelwal, and Adam Osman. 2015. "Exporting and Firm Performance: Evidence from a Randomized Trial." Working Paper no. 20690. Cambridge, Mass.: National Bureau of Economic Research. https:// dl.dropboxusercontent.com/u/2960823/Egypt_experiment.pdf

Berkowitz, Daniel, Hong Ma, and Shuichiro Nishioka. 2014. "Recasting the Iron Rice Bowl: The Reform of China's State Owned Enterprises." Working Paper. (Revised version presented at the 2015 Annual Meeting of the International Society of New Institutional Economics.) https://www.aeaweb.org/aea/ 2015conference/program/retrieve.php?pdfid=807.

Calomiris, Charles W., Raymond Fisman, and Yongxiang Wang. 2010. "Profiting from Government Stakes in a Command Economy: Evidence from Chinese Asset Sales." Journal of Financial Economics 96, no. 3: 399-412.

De Loecker, Jan. 2007. "Do Exports Generate Higher Productivity? Evidence from Slovenia." Journal of International Economics 73, no. 1: 69-98.

Fan, Joseph, Randall Morck, and Bernard Yeung. 2011. "Capitalizing China." Working Paper no. 17687. Cambridge, Mass.: National Bureau of Economic Research.

Fewsmith, Joseph. 2001. "The Political and Social Implications of China's Accession to the WTO." China Quarterly 167: 573-91.

Fisman, Raymond, and Yongxiang Wang. 2015. "The Mortality Cost of Political Connections." Working Paper no. 21266. Cambridge, Mass.: National Bureau of Economic Research.

Khandelwal, Amit K., Peter K. Schott, and Shang-Jin Wei. 2013. "Trade Liberalization and Embedded Institutional Reform: Evidence from Chinese Exporters." American Economic Review 103, no. 6: 2169-95.

Kowalski, Przemyslaw, Max Büge, Monika Sztajerowska, and Matias Egeland. 2013. "State-Owned Enterprises: Trade Effects and Policy Implications." OECD Trade Policy Papers no. 147. Paris: Organisation for Economic Cooperation and Development.

Lardy, Nicholas R. 2014. Markets over Mao: The Rise of Private Business in China. Washington: Peterson Institute for International Economics. 
McGregor, Richard. 2012. The Party: The Secret World of China's Communist Rulers. New York: Harper Perennial.

Tang, Heiwei, Fei Wang, and Zhi Wang. 2014. "The Domestic Segment of Global Supply Chains in China under State Capitalism." Policy Research Working Paper no. 6960. Washington: World Bank.

Tang, Man-Keung, and Shang-Jin Wei. 2009. "The Value of Making Commitments Externally: Evidence from WTO Accessions." Journal of International Economics 78, no. 2: 216-29.

GENERAL DISCUSSION John Haltiwanger opened the discussion of Chang-Tai Hsieh and Zheng Song's paper by noting how struck he was by the high exit rates the authors found for small state-owned enterprises (SOEs) in China relative to large ones. In the United States, exit rates and job destruction rates are much higher for small businesses, since big businesses can downsize without shutting down, but Haltiwanger had found when he studied transitional economies during the 1990s that job destruction rates for large firms actually exceeded those for small firms. His interpretation was that the big state-owned enterprises were unable to survive in the new competitive environment. So this finding about China puzzled him. If the authors went back and examined job destruction rates by firm size, might they discover the same pattern he had?

Donald Kohn saw possible consequences for China stemming from the interaction of its financial reform and the SOEs. First, freeing up interest rates to rise to market levels might put pressure on SOEs that would lead them to shrink. On the other hand, concern that the SOEs might not be able to do very well in a freer financial market could slow down the party's reform of the financial sector.

David Romer summed up the rhetoric of reform in China this way: You start with a heavily centrally planned economy, decide to improve it by shifting resources to the private sector, and expect to see wonderful results. But the direct contribution from closing and privatizing SOEs is so small it is basically a rounding error in China's overall growth, which is astonishing. An equally interesting finding is that reforms within the remaining state sector may account for a big chunk of growth. But, Romer asked, what has been going on with the remaining 75 percent of the economic growth, which the authors acknowledge they have not explained? He saw two possibilities. One was that the private sector grew relative to the stateowned sector not by SOEs' being shut down and so freeing up resources but, as Haltiwanger said, just by laying off workers, making the SOE sec- 
tor smaller and the private sector larger. In effect it would be another way of privatizing. A second possibility, however, is that there has been very rapid growth in the productivity of all firms, both state and private. In that case, China has not been following the "Capitalism 101" scenario at all, but something very different.

David Lagakos asked whether the paper's findings were also present in a narrower set of industries where output (and hence productivity) is measured with the least error. He mentioned a tradition in the study of total factor productivity of examining narrowly defined industries where output is reasonably homogeneous, as has been done quite effectively in studies of the iron ore, steel, and concrete industries. The paper would be even more compelling if its findings showed up as well in some narrowly defined sectors such as these, where we are less worried about measurement issues.

Hsieh responded to David Romer's question on the missing 75 percent by noting that 80 percent of China's growth can be explained by the massive entry of new private firms, as discussant Loren Brandt stated. Moreover, it is a particular type of private firm: very large ones. Although that may not sound very insightful, it may be the answer to one of the biggest puzzles in China today. After all, none of the institutions classically required for a vibrant free-market economy - private property rights, an independent judicial system, and so on-yet exists in China.

Hsieh believes that 80 percent of growth is essentially the Sinovel story, multiplied many times over. Private entrepreneurs cut deals with Communist Party bosses and, as a result, most private firms today look like Sinovel in their structure. One could describe this as an efficiency-enhancing form of theft. Assets that were not being used efficiently under the institutional structure were stolen, and then the residual claimant set out to make the company work in the marketplace.

Responding to Kohn's comment, Hsieh agreed that the main barrier to freeing up rates in the banking system is the vested interests of the SOEs. He saw two potential escape valves. One is what has happened over the last five or six years in China: the development of a shadow banking system. These banks have invested money in property, which has led to a great deal of overbuilt real estate in every city, and also invested in these new private firms. The shadow banks that Hsieh has been able to trace are murky institutions essentially owned by local governments, so their money is associated with the local party bosses. A second escape valve, at least for some firms, has been access to loans from the official banking sector. This too occurs by making deals with party bosses, who in exchange for favors provide access to credit from the state-owned banks. 
His sense is that any improvement in the efficiency of the allocation of capital in China is likely to come from one of these two mechanisms, the shadow banking mechanism being the more important because it is so large. Yet it is also completely unregulated, so it comes with its own high risk, reminding him of the run-up to the financial crisis in Chile in 1982.

In response to Haltiwanger, Hsieh added that the exit rates for small firms in China, at about 25 to 35 percent per year, are actually much higher than in the United States. He agreed with Haltiwanger's suggestion to look at job destruction by firm size. He has already found that among SOEs, output per worker rose more than total output, indicating that growth has been enabled by a combination of downsizing and firm restructuring.

Brad DeLong admitted that the more good papers on China he has read the more uneasy he has become - and the less he feels he understands. One of the few historical patterns to repeat itself with regularity over the past three centuries has been that, wherever governments are unable to make the allocation of property and contract rights stick, industrialization never reaches North Atlantic levels of productivity. Sometimes the benefits of entrepreneurship are skimmed off by roving thieves. Sometimes economic growth stalls. Or sometimes profits are skimmed by local notables who abuse what ought to be the state's powers for their own ends. China has failed to make its allocation of property rights stick in any meaningful sense through the rule of law. Instead, it seems to have adopted a form of industrial neofeudalism.

Such a system should not work: The party bosses with special rights to enterprises should find themselves unable to referee disputes among one another. The same shortsighted rent-extraction logic should apply in China as has played out in Eastern Europe, sub-Saharan Africa, Southeast Asia, South Asia, and Latin America. And yet, somehow, it seems to be working in China.

Robert Hall said that while he appreciated DeLong's puzzlement about an economy lacking Adam Smith's free markets, property rights, and rule of law seeing such unprecedented growth as China's, cross-sectional research on productivity and output per worker has reached some different conclusions. Among them is the idea of a competent government that generates high levels of output per worker. China had an incompetent government under Mao but has moved in the direction of competence. For example, the government has allowed SOEs to be publicly traded, which enables the market to send a signal about what is going on inside of companies. And China is not the first example where government competence has mattered 
in this way: the spectacular growth of Singapore was also founded on such competence and not just on Adam Smith.

Christopher Carroll introduced a new point: the circumstances under which transitional countries seem able to achieve rapid growth, when they have started from almost nothing, are very different from the circumstances that contribute to achieving or remaining at the North Atlantic frontier. Chinese output per capita in 1978 was not much higher than it had been in 1700 , and therefore the institutions now in place there are not likely to get the country to the North Atlantic frontier. For the same reason, the institutions in Stalinist Russia never succeeded in getting the Soviet Union to the North Atlantic frontier, even though a lot of economic growth occurred in the Soviet Union.

Caroline Hoxby observed that in studies of productivity she did in the 1990s looking at different industries across countries, she had found that exposure to competition was probably the most important factor, even more important than ownership. If that is what has happened in Chinathat they have created competition in some of the industries-it could help explain the rapid productivity growth, whether it is occurring in the SOEs or in the private enterprises.

David Romer echoed DeLong's point that what is happening in China remains a dark puzzle. He recalled an NBER Macroeconomics Annual Meeting in the late 1990s where the broad consensus in the room was that Russia was doing everything right by moving rapidly to a market system, privatizing as quickly as possible, whereas China was making a terrible mistake and its success would not last. The reality has turned out very differently. He also had an additional question for the authors: How can Hsieh's statement that new private firms often took shape through theft from the state sector be reconciled with the paper's finding that only 3.2 percent of the country's growth stemmed from moving resources out of the state sector into the private sector, where they are more productive?

Hsieh responded to the comments. To clarify what he meant when he spoke of theft from the state sector, he said what an entrepreneur in China might do is similar to what an entrepreneur in the United States might do when he pitches an idea to a venture capitalist. In China that entrepreneur is also looking for investment. In every one of China's 3,000 cities there is a local Communist Party boss, and investment pitches are made to them over dinner. These deals can be implicit: "If you support my enterprise I'll be eternally grateful," and that gratitude later takes the form of (for example) paying for the boss's child to go to Stanford without ever being asked to. Sometimes deals are explicit: they can take the form of giving out 
equity shares in the firm, although since that is officially illegal the shares would be in the name of the boss's wife's grand-uncle as shareholder. The question for economists is, How well does this kind of system actually work? This goes back to a more basic question: How much can these party bosses do for those entrepreneurs?

Hsieh agreed with Hall that local governments in China, while incompetent in certain things, have proven to be very competent when they put their mind to getting something done. This includes some activities that people in free societies consider terrible, such as enforcement of the one-child policy, which often takes up the largest number of government employees in a region. In purely administrative terms, carrying out that policy is incredibly hard work, because it requires inspecting every single home, so it reflects a certain kind of competence. Over the last 20 years that capacity has been channeled toward supporting certain kinds of businesses by making deals.

One might compare China's growth with what has been happening in South Korea over the last 30 years. The growth in South Korea has not come from the creation of new corporate groups but from the creation of new companies within the given groups. There, a company like Samsung, which alone accounts for 30 percent of South Korea's GDP, has been incredibly entrepreneurial in its ventures into new sectors and new products. Hsieh suggested that over the last 20 years something equivalent to that has been happening in China, where each local government is spinning off a web of private companies through this system of party-boss-sponsored investment. It may be different in the future, but over recent decades that is where most of the growth has come from. The SOE growth that his paper analyzed is only one small part of that. 